107 Royal Netherlands Institute for Sea Research

This is a postprint of:

Steinhardt, J., Cléroux, C., Ullgren, J.E., de Nooijer, L.J., Durgadoo, J.V., Brummer, G.-J., \& Reichart, G.-J. (2014). Anticyclonic eddy imprint on calcite geochemistry of several planktonic foraminiferal species in the Mozambique Channel. Marine Micropaleontology, 113, 20-33

Published version: $\underline{\mathrm{dx} . \mathrm{doi} . \mathrm{org} / 10.1016 / \mathrm{j} \text {.marmicro.2014.09.0 }}$

Link NIOZ Repository: www.vliz.be/nl/imis?module=ref\&refid=243544

[Article begins on next page]

The NIOZ Repository gives free access to the digital collection of the work of the Royal Netherlands Institute for Sea Research. This archive is managed according to the principles of the Open Access Movement, and the Open Archive Initiative. Each publication should be cited to its original source - please use the reference as presented.

When using parts of, or whole publications in your own work, permission from the author(s) or copyright holder(s) is always needed. 


\section{Anti-cyclonic eddy imprint on calcite geochemistry of several planktonic foraminiferal species in the Mozambique Channel}

Juliane Steinhardt", Caroline Cléroux*, Jenny Ullgren\#, Lennart de Nooijer*, Jonathan V. Durgadoo $^{x}$, Geert-Jan Brummer ${ }^{\star}$, , Gert-Jan Reichart ${ }^{* 0}$

\footnotetext{
*The Royal Netherlands Institute for Sea Research (NIOZ), P.O. Box 59, 1790 AB Den Burg, Texel, The Netherlands

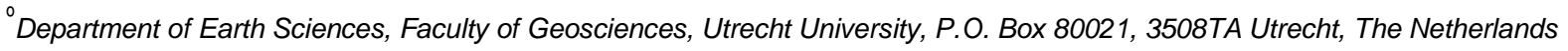

"Nansen Environmental and Remote Sensing Center, Thormøhlens gate 47, 5006 Bergen, Norway

${ }^{\triangle}$ Faculty of Earth- and Life Sciences, VU University Amsterdam, de Boelelaan 1085, 1081 HV Amsterdam, The Netherlands

× GEOMAR Helmholtz Centre for Ocean Research Kiel, Kiel, Germany

Corresponding author: juliane.steinhardt@nioz.nl
}

\section{Abstract}

Hydrographic conditions in the Mozambique Channel are dominated by the passing of large anticyclonic eddies, propagating poleward into the upstream Agulhas area. Further south, these eddies have been found to control the shedding of Agulhas rings into the Atlantic ocean, thereby playing a key role in Indo-Atlantic Ocean exchange. The element composition of several planktonic foraminifera species collected from sediment trap samples, was compared to in situ water column data from the Mozambique Channel. Single-chamber trace element composition of these foraminifera reveals a close coupling with hydrographic changes induced by anticyclonic eddies. Obtained Mg/Ca values for the surface dwelling Globigerinoides ruber as well as the thermocline dwelling Neogloboquadrina dutertrei follow temperature changes and reduced temperature stratification during eddy conditions. At greater depth, Globorotalia scitula and Pulleniatina obliquiloculata record stable temperatures and thus respond to hydrographic changes with a deepening in habitat depth. Furthermore, test $\mathrm{Mn} / \mathrm{Ca}$ values indicate a close relationship between water column oxygenation and $\mathrm{Mn}$ incorporation in these planktonic foraminiferal species.

\section{Introduction}

Mesoscale eddies play a crucial role in transporting water (e.g. Schouten et al., 2002) and heat (Bryan, 1986; Sallée et al., 2008) over long distances, thereby promoting large-scale mixing of the ocean (Lutjeharms et al., 1989; Ballegooyen et al., 1994; De Ruijter et al., 1999). In addition to the 
well-studied eddies within the Gulf Stream and Kuroshio Current (Cronin and Watts, 1996; Mensa et al., 2013), eddies are ubiquitous and found in many regions (e.g. McGillicuddy et al., 1998; Martin and Richards, 2001; Mackas et al., 2005; Kolasinski et al., 2012). Eddies also transport nutrients, salt and other chemicals (Bakun, 2006; Xiu et al., 2011), thereby regulating marine species abundances and community composition (Owen, 1981; Sabarros et al., 2009; Huggett, 2013; Lamont et al., 2013). Cyclonic eddies rotate clockwise in the Southern Hemisphere and carry a cold water core, corresponding to a reduced sea surface height. Anticyclonic (anticlockwise) eddies are characterized by a warm water core and associated with elevated sea surface height. The impact of eddy activity is not confined to the sea surface but affects deeper and in some cases, bottom water conditions. Oceanographers in the 1960's placed drifters and floats at depth providing evidence of meso-scale eddy features (Cook, 1966; Send et al., 1999). Since then satellite images of SST, ocean colour and altimetry have been applied to detect and study eddies (e.g. Fu et al., 2010). Considering their ubiquitousness, it is expected that eddies affect the circulation in large parts of the global ocean system. Eddies being shed from the Agulhas Current into the Atlantic Ocean, so called "Agulhas leakage", is among the better described examples of the impact of eddies on climate. Global warming, as observed currently, is likely to cause a further increase in Agulhas leakage (Biastoch and Böning, 2013), thereby affecting ocean mixing and biogeochemical dynamics, which in turn might influence climate. This relation implies an unexplored feedback mechanism potentially affecting the global climate system.

The Agulhas Current, one of the major western boundary currents, plays a crucial role in the global ocean conveyor circulation (Gordon et al., 1992; Weijer et al., 2002). By shedding rings, eddies and filaments into the South Atlantic, Agulhas leakage supplies warm and saline water from the Indian Ocean into the Atlantic (Gordon, 1986; Gordon et al., 1992; De Ruijter et al., 1999; Beal et al., 2011) thereby influencing Atlantic meridional overturning circulation (AMOC) (Biastoch et al., 2008). Records of past changes in Agulhas leakage based on planktonic foraminiferal assemblages (Peeters et al., 2004) showed a link to glacial-interglacial cycles. The salt export into the Atlantic basin by Agulhas eddies is hypothesized to provide the negative overall buoyancy needed for deep-water formation in the North Atlantic (Weijer et al., 2001; 2002).

Up-stream of the Agulhas Current, eddies in the Mozambique Channel propagate poleward into the Agulhas Retroflection where they have been shown to occasionally trigger shedding of Agulhas Rings (Schouten et al., 2002). There are extensive records from satellite sensors, in situ observations and numerical models, which can be used collectively to study and interpret eddyinduced environmental impacts (e.g. Byrne et al., 1995; Biastoch and Krauss, 1999; De Ruijter et al., 2002; Backeberg et al., 2012). A recent model study (Backeberg et al., 2012) suggested an 
increase in eddy kinetic energy between 1993 and 2009, resulting in a doubling of the pole ward propagation of anticyclones. Flow from the Mozambique Channel and the southern extension of the East Madagascar Current (EMC) are both considered to be important sources for the Agulhas Current (Schouten et al., 2002; De Ruijter et al., 2004). This implies that intensification of the mean flow and its mesoscale variability may have downstream implications for the Agulhas Current and could thereby influence leakage into the South Atlantic Ocean. To study the interplay between eddy activity and large-scale climate variability, reconstructing past eddy activity could provide valuable information. Here we propose a novel approach based on the chemical composition of planktonic foraminiferal calcite tests to develop such a proxy. We selected specimens from sediment trap times series in the Mozambique Channel where eddies are frequent and long-term oceanographic observations available (Ullgren et al., 2012). Long-term moorings in the center of the Mozambique Channel show that five to seven large anticyclonic eddies with a diameter of $>300 \mathrm{~km}$ pass southwards every year (Schouten et al., 2002; Harlander et al., 2009). These eddies can extend down to depths of $1.5 \mathrm{~km}$ (De Ruijter et al., 2002; Ullgren et al., 2012) and account for up to $30-40 \%$ of the observed hydrographic variability.

Here we present single-chamber trace element compositions from specimens with contrasting calcification depths, the surface-dweller Globigerinoides ruber (d' Orbigny, 1839), thermoclinedwelling species Neogloboquadrina dutertrei (d' Orbigny, 1839) and Pulleniatina obliquiloculata (Parker et al., 1865) and the deep dweller Globorotalia scitula (Brady, 1882). Specimens were collected from sediment trap samples and analyzed using laser ablation-inductively coupled plasma-mass spectrometry (LA-ICP-MS). Obtained element/Ca ratios will allow calibrating incorporation of e.g. magnesium and manganese in planktonic foraminifera in function of in situ hydrographic conditions, both during eddy and non-eddy conditions and compare incorporation of these elements in the surface versus sub-surface water column.

\section{Materials and methods}

\subsection{Oceanographic setting}

The Mozambique Channel (MC) is an oligotrophic region with concentrations of chlorophyll $a$ in surface waters between $0.3 \mathrm{mg} / \mathrm{m}^{3}$ in summer and $0.25 \mathrm{mg} / \mathrm{m}^{3}$ in winter. Seawater temperatures (SST) in the MC vary seasonally and with eddy-induced transport (Fallet et al., 2011a). The seasonal temperature forcing is associated with the monsoon system and is reflected by sea surface temperatures (SST) ranging from $25^{\circ} \mathrm{C}$ to more than $30^{\circ} \mathrm{C}$ with an annual mean of $27.6^{\circ} \mathrm{C}$. With the onset of austral summer, rainfall increase caused by the seasonal migration of the ITCZ, sea surface salinities decrease slightly from 35.2 in winter to 34.9 in summer (Fallet et al., 2010). 
The main water masses of the upper layer in the MC include the Tropical Surface Water (TSW), Subtropical Surface Water (STSW) and Indonesian Throughflow Water (ITFW). The warm, fresh surface water (TSW) forms in the tropics and is transported westward within or north of the South Equatorial Current (SEC, New et al., 2007). Close to the western margin, where the SEC bifurcates, warm surface waters are transported poleward, either east of Madagascar, or through the Mozambique Channel (e.g. Gründlingh, 1995; Swallow et al., 1988). The STSW is characterized by relatively high salinities and a subsurface maximum, with salinities of $35.2-35.5$, at approximately 200 meters below sea surface, at which depth the surface water subducts below the fresher TSW (Wyrtki, 1973). Southward migration of anticyclonic meso-scale eddies, originating at $10^{\circ} \mathrm{S}$ north off the Comoros Islands, affects the Mozambique Channel hydrography [Figure 1]. Mozambique Channel eddies have high rotational velocities, often above $1.5 \mathrm{~m} / \mathrm{s}$ (Schouten et al., 2003; Ullgren et al., 2012). These eddies pass through the channel at a mean frequency of about four to seven per year (at a southward propagation speed of 3-6 km.d-1) before joining the Agulhas Current. An eddy passage is associated with vertical movement of isopycnals, which can occasionally exceed $40 \mathrm{~m}$ per day in the upper layer (Ullgren et al., 2012). Backeberg and Reason (2010) suggested that formation of meso-scale eddies in the Mozambique Channel is related to variability in SEC transport [Figure 1].

\subsection{Sediment trap and mooring array}

Ongoing observations started in November 2003, as part of the Long-term Ocean Climate Observations (LOCO) program, with an array of eight moorings across the narrowest part of the channel, providing continuous current velocities, temperature and salinity measurements at fixed depths. Over the period 2003 to 2009 , the average volume transport was estimated at -17 Sv (1 $\mathrm{Sv}=10^{6} \mathrm{~m}^{3} \mathrm{~s}^{-1}$; negative poleward), daily values ranging between -65 and $45 \mathrm{~Sv}$ (Ullgren et al., 2012). Below the poleward mean flow, a deep undercurrent is flowing in the opposite direction along the continental slope (De Ruijter et al., 2002; Harlander et al., 2009; Ridderinkhof et al., 2010). For this study, we used temperatures recorded at 110 meters; 200 meters and 400 meters water depth by a CTD deployed on mooring $\operatorname{Imc5A}\left(16.8^{\circ} \mathrm{S}, 41.1^{\circ} \mathrm{E}\right.$, Figure 2$)$, which is closest to the trap site. Additionally, we obtained averaged daily SST from the $4 \mathrm{~km}$ daytime MODIS/AQUA dataset for the area $16-17^{\circ} \mathrm{S}$ and $40-41^{\circ} \mathrm{E}$ (trap site) for the period of the selected sediment trap intervals (http://poet.jpl.nasa.gov/).

Technicap PPS 5 sediment traps were deployed at $16.8^{\circ} \mathrm{S}$ and $40.8^{\circ} \mathrm{E}$ in the central MC [Figure 1]. Equipped with a 24-cup automated sampling carousel and a baffled collecting area of $1 \mathrm{~m}^{2}$, the 
trap was positioned 250 meters above the channel floor at 2250 meters water depth. In total four sediment trap deployments took place between November 2003 and February 2009, each programmed to a 17, 21 or 23 days sampling interval. Prior to deployments, sample cups were filled with an $\mathrm{HgCl}_{2}$-poisoned and borax-buffered solution of seawater collected from the deployments depth (Loncaric et al., 2007). Time-series sediment trap samples were wet-split, sieved and foraminiferal shells were cleaned as previously described (Fallet et al., 2009; 2010).

\subsection{Eddy/ non-eddy detections \& sample selection}

The passing of an anticyclonic eddy through the narrows of the Channel is marked by high temperature and salinity, as well as high dynamic height in the satellite altimetry record. At the leading (southern) edge of the eddy with a diameter of up to $300 \mathrm{~km}$ (De Ruijter et al., 2002), current velocities are expected to have a predominant eastward component, whereas a zonal section across the center of the eddy would show a strong southward flow on the western side and a northward component on the eastern side, and the trailing (northern) edge of the eddy should show a westward component. An eddy core passing through the LOCO mooring section thus coincides with a peak in the difference between meridional current velocity on the eastern and western side of the mooring array. The meridional current velocity averaged over the upper $500 \mathrm{~m}$ at mooring Imc5 on the western side of the array was subtracted from the similarly averaged meridional velocity at Imc8 on the eastern side to give a measure of the lateral current shear across the Channel, which was used as a proxy for eddy presence at the mooring section. The lateral current shear from in situ measurements was combined with dynamic heights from satellite altimetry in order to define periods when eddies were present at the section. An eddy core was considered to be at the mooring section when there was a local maximum in dynamic height at $41.3^{\circ} \mathrm{E}$ greater than $10 \mathrm{~cm}$ above surrounding values, coinciding with a maximum in absolute lateral current shear within 10 days. This measure corresponded well with the hydrographic eddy signatures in temperature and salinity; for example maxima in subsurface temperature measured by the moorings correlate well with the peaks in dynamic height or velocity shear.

We are not only concerned with the timing of eddy cores at the section, but rather with accounting for the full period in which an eddy passes the sediment traps location. For this reason we defined "eddy segments" as a period between two dynamic height minima which contains one well-defined combined maximum of dynamic height and lateral velocity shear, following the criteria outlined above. We selected the sediment trap intervals during which the whole sediment cup collection took place under either full eddy or full non-eddy conditions. The following three intervals were 
appointed as representing non-eddy conditions: MOZ1 A07 (28 March - 17 April 2004), MOZ2 A11 (25 October -16 November 2005), and MOZ4 A01 (1 - 17 February 2008). The three intervals representing eddy conditions were MOZ1 A08 (18 April - 08 May 2004), MOZ2 A12 (17 November - 9 December 2005), and MOZ4 A06 (26 April - 12 May 2008). Eddy variability in the upper and intermediate waters is dominated by the effect of temperature, whereas salinity only has a minor effect (Ullgren et al., 2012). For the chosen sediment trap intervals, temperature observations from the mooring (Imc5a), are compiled and daily means were used to calculate eddy and non-eddy temperature profiles [Figure 2]. Mean conditions during the selected eddy and non-eddy intervals show that eddy conditions are associated with warmer upper water columns.

To ensure that the planktonic foraminifera are not derived from long-distance transport, but rather formed and settled locally within the Mozambique Channel, we simulated the provenance of virtual particles within the high-resolution INALT01 model (Durgadoo et al., 2013). INALT01 has been shown to represent the intricacies of the greater Agulhas Current system faithfully (Durgadoo et al., 2013). For these calculations, $\sim 10,000$ particles, representing planktonic foraminifera, were released within a hind-cast experiment at the location and depth of the sediment trap. Back trajectories were calculated in two steps: first (representing the last phase of transport of shells to the trap) relatively fast sinking occurs after the foraminifera die, second (occurring earlier) followed by back tracking living foraminifera and confinement to a specific depth interval. This way we calculated the likelihood for particular locations being the origin of the trapped foraminifera. Assuming an average sinking speed of $\sim 1 \mathrm{~cm} \mathrm{~s}^{-}$after death (Takahashi and Bé, 1984), foraminiferal shells reached the depth of the sediment trap within approximately 3 days. Prior to this sinking stage foraminiferal tests were assumed to have travelled at 25, 50 and 150 meters water depth respectively, and were thus back-tracked for 6 weeks (assuming this as an average lifespan for the planktonic foraminiferal species used here (Hemleben et al., 1986; Loncaric et al., 2006)). The back-trajectory model-results show that the majority of the foraminifera captured by our sediment trap originated from the $\mathrm{MC}$ and hence are suitable to trace hydrographic changes within the MC [Figure 3].

\subsection{Species selection and chamber analysis used for proxy development}

We selected four planktonic foraminiferal species, suggested to dwell at different depth intervals in the water column for element analyses of their carbonate tests. Globigerinoides ruber white is a shallow dwelling species (0 - 50 meters), often used to reconstruct SST (Hemleben et al., 1989). The subsurface-dwellers Neogloboquadrina dutertrei and Pulleniatina obliquiloculata have been associated with a calcification depth of 0 - 100 meters and 60 - 150 meters in the upper and middle 
thermocline, respectively (Erez and Honjo, 1981; Fairbanks et al., 1982; Ravelo and Fairbanks, 1992; Pflaumann and Jian, 1999; Spero et al., 2003; Field, 2004; Kuroyanagi and Kawahata, 2004; Cléroux et al., 2007; Huang et al., 2008). We also included the deep-dwelling species Globorotalia scitula to analyse deep water conditions (Bé, 1969; Ortiz et al., 1996; Itou et al., 2001; Fallet et al., 2011). This set of foraminiferal species should therefore cover the vertical extend of the upper water column and thereby the most pronounced changes associated with eddy variability.

Specimens were selected from the 250 - $315 \mu \mathrm{m}$ size fraction as much as possible. In case sufficient specimens from the designated trap samples were not available within this size range for replicate LA-ICP-MS analyses larger specimens were also used, which is indicated in table S1 (Supplementary material). For G. ruber we ablated the penultimate- and pre-penultimate chamber (F-1 or F-2 chambers) and results for both chambers were combined to calculate relevant averages, since no significant differences for $\mathrm{Mg} / \mathrm{Ca}$ between chambers were observed (see result section 3.1). For $N$. dutertrei, $P$. obliquiloculata and $G$. scitula we ablated the final three to four chambers. Previously a size effect was suggested for $\mathrm{G}$. ruber whole test $\mathrm{Mg} / \mathrm{Ca}$ values (Friedrich et al., 2012). Still, Friedrich et al. (2012) observed almost no change between the $250-300 \mu \mathrm{m}$ and $300-350 \mu \mathrm{m}$ size fractions and hence, in view of the rather narrow size interval used here (250-315 $\mu \mathrm{m}), \mathrm{Mg} / \mathrm{Ca}$ differences related to size are likely to be negligible. This is also in line with $\mathrm{Ni}$ et al., (2007), who showed that variability of $\mathrm{Mg} / \mathrm{Ca}$ ratio with test size is largely negligible. Also when using laser ablation ICP-MS limiting the size range is a good way to excluded a major ontogenetic effect on single-specimen Mg/Ca-derived temperatures (Wit et al., 2010).

\subsection{LA-ICP-MS}

Element/Ca ratios (e.g., Mg/Ca) of single chambers were determined by LA-ICP-MS at Utrecht University (Reichart et al., 2003). A GeoLas 200 Q Excimer $193 \mathrm{~nm}$ deep ultra violet laser (Lambda Physik) was used to ablate circular craters of 60 or $80 \mu \mathrm{m}$ in diameter depending on the surface area of the chambers. Energy density at the sample surface was approximately $1 \mathrm{~J} \mathrm{~cm}^{-2}$ and all samples were ablated with a repetition rate of $7 \mathrm{~Hz}$ in a $\mathrm{He}$ atmosphere. The sector field mass spectrometer (Element 2, Thermo Scientific) was run in low-resolution mode and masses monitored included ${ }^{23} \mathrm{Na},{ }^{24} \mathrm{Mg},{ }^{26} \mathrm{Mg},{ }^{27} \mathrm{Al},{ }^{43} \mathrm{Ca},{ }^{44} \mathrm{Ca},{ }^{55} \mathrm{Mn},{ }^{88} \mathrm{Sr},{ }^{114} \mathrm{Cd},{ }^{138} \mathrm{Ba}$ and ${ }^{238} \mathrm{U}$. Calibration was performed against SRM NIST610 glass standard (using values from Jochum et al., 2011), with ${ }^{43} \mathrm{Ca}$ as an internal standard, which was ablated at higher energy density $\left(5 \mathrm{~J} \mathrm{~cm}^{-2}\right) 3$ times between every 10 - 12 foraminiferal samples. A matrix matched, homogenous calcite crystal 
(Icelandspar) with known Mg/Ca was ablated to check for matrix dependent fractionation caused by the different energy densities when switching between glass and calcium carbonate (DueñasBohórquez et al., 2011). Concentrations of $\mathrm{Mg}$ in the foraminiferal shell were calculated using count rates for ${ }^{24} \mathrm{Mg}$. Concentrations of $\mathrm{Mg}$ and confidence intervals for each individual measurement were calculated using the Glitter software (Glitter, Maquarie Research Limited, 1999 - 2000). The matrix matched in-house standard showed average relative standard deviations (SD) of $3.7 \%$ for $\mathrm{Mg} / \mathrm{Ca}$ and $3.2 \%$ for $\mathrm{Mn} / \mathrm{Ca}$. Measurements were performed on intact specimens and always proceeded from the outside towards the inside [Figure 4]. In total, 536 single-chamber $\mathrm{Me} / \mathrm{Ca}$ values were obtained. We do not consider variability (and outliers) within the profiles. Values deviating more than twice the standard deviation from the initial dataset were regarded as outliers and discarded from the initial dataset. In total we discarded $19 \mathrm{Mg} / \mathrm{Ca}$ values based on an outlier analysis.

\subsection{Mg/Ca calibrations}

Mg incorporation into foraminiferal calcite is related to temperature and likely affected by a combination of thermodynamic controls and foraminiferal physiology (Bentov and Erez, 2006; Rosenthal et al., 1997). For many planktonic species it was shown that calcitic $\mathrm{Mg} / \mathrm{Ca}$ varies exponentially with calcification temperature (Lea et al., 1999; Nürnberg et al., 1996; Rosenthal et al., 2000; Anand et al., 2003; Cléroux et al., 2008) in the form:

$$
\mathrm{Mg} / \mathrm{Ca}\left[\mathrm{mmol} \mathrm{mol}{ }^{-1}\right]=B^{*} \mathrm{e}^{A T}
$$

The exponential constant $(A)$ reflects temperature sensitivity. For many species, it is reported to be between 0.09 and 0.10 (e.g. Anand et al., 2003). The pre-exponential constant (B) is speciesspecific and may also vary with differences in size fraction used, cleaning protocols and dissolution effects (Anand et al., 2003; Fallet et al., 2010).

We used the following equations to translate measured $\mathrm{Mg} / \mathrm{Ca}$ ratios into calcification temperatures:

a) G. ruber: $\mathrm{Mg} / \mathrm{Ca}=$ [SST-15.71]/2.32 (Fallet et al., 2010)

b) N. dutertrei: $\mathrm{Mg} / \mathrm{Ca}=0.342^{*} \exp \left(0.09^{\star} \mathrm{T}\right.$ ) (Anand et al., 2003)

c) P. obliquiloculata: $\mathrm{Mg} / \mathrm{Ca}=0.328^{*} \exp \left(0.09^{\star} \mathrm{T}\right)$ (Anand et al., 2003)

d) G. scitula: $\mathrm{Mg} / \mathrm{Ca}=0.409^{*} \exp \left(0.09^{*} \mathrm{~T}\right)$ (Anand et al., 2003) 
These calibrations are all based on whole multiple test analyses from sediment trap samples. Previous studies showed that both single-chamber and multiple-shells $\mathrm{Mg} / \mathrm{Ca}$ data are similarly correlated to temperature (Hathorne et al., 2003; Reichart et al., 2003). Recent culture studies (e.g. Dueñas-Bohórquez et al., 2009) also found that data from multiple individual chambers are consistent with previously derived whole-foraminiferal test calibrations.

The calibration for $G$. ruber from Fallet et al. (2010) was recently derived using the same sediment trap material as used here. Over the temperature range considered here the calibrations of Fallet et al. (2010) and the calibration for G. ruber of Anand et al. (2003) $\left(\mathrm{Mg} / \mathrm{Ca}=0.449^{*} \exp \left(0.09^{\star} \mathrm{T}\right)\right)$ are very similar. Still, since the calibration of Fallet et al. (2010) is based on the local seasonal temperature cycle, this calibration is probably best suited for our purposes. For $N$. dutertrei and $P$. obliquiloculata we applied species-specific calibrations from the sediment trap time-series from the North Atlantic Ocean (Anand et al., 2003). Because no species specific calibration is available for G. scitula we applied a calibration based on G. hirsuta (Anand et al., 2003). This seems reasonable since both species are Globorotalids, having similar depth habitats and $\mathrm{Mg} / \mathrm{Ca}$ values within the same range ( $1-2 \mathrm{mmol} / \mathrm{mol})$. Importantly, since here we focus on differences between eddy and non-eddy conditions, the calibrations used as such are less important as this mainly affects absolute temperatures.

\section{Results:}

\subsection{Mean $\mathrm{Me} / \mathrm{Ca}$ ratios}

\section{$\mathrm{Mg} / \mathrm{Ca}$}

Average $\mathrm{Mg} / \mathrm{Ca}$ values of $G$. ruber are highest, followed by those of $N$. dutertrei, $P$. obliquilocuata and lowest values are observed in $\mathrm{G}$. scitula tests [Figure 5]. Average $\mathrm{Mg} / \mathrm{Ca}$ values for $\mathrm{N}$. dutertrei (2.6 $\mathrm{mmol} / \mathrm{mol}$, standard error: (SE): $0.06 \mathrm{mmol} / \mathrm{mol}, \mathrm{N}=228$ ) correspond to lower temperature $\left(22.5^{\circ} \mathrm{C}\right)$ compared to those based on $\mathrm{Mg} / \mathrm{Ca}$ G. ruber $(\mathrm{Mg} / \mathrm{Ca}=5.32 \mathrm{mmol} / \mathrm{mol}$, SE: 0.09 $\left.\mathrm{mmol} / \mathrm{mol}, \mathrm{N}=176,28.1^{\circ} \mathrm{C}\right) . \mathrm{Mg} / \mathrm{Ca}$ values of $N$. dutertrei and $P$. obliquiloculata $(2.29 \mathrm{mmol} / \mathrm{mol}$, SE: $\left.0.1 \mathrm{mmol} / \mathrm{mol}, \mathrm{N}=47,21.6^{\circ} \mathrm{C}\right)$ are similar, $\mathrm{Mg} / \mathrm{Ca}$ values for $\mathrm{G}$. scitula are the lowest $(1.5$ $\mathrm{mmol} / \mathrm{mol}, \mathrm{SE}: 0.07 \mathrm{mmol} / \mathrm{mol}, \mathrm{N}=100$ ) [Figure 4], corresponding to temperatures of $14.4^{\circ} \mathrm{C}$. The inter-test variability is highest in G. ruber (standard deviation (SD): $\pm 1.2 \mathrm{mmol} / \mathrm{mol}$ ), followed by $N$. dutertrei (SD: $\pm 1.0 \mathrm{mmol} / \mathrm{mol}$ ), $P$. obliquiloculata (SD: $\pm 0.6 \mathrm{mmol} / \mathrm{mol}$ ), with lowest spread in $G$. scitula (SD: $\pm 0.4 \mathrm{mmol} / \mathrm{mol})$. 
Average $\mathrm{Mg} / \mathrm{Ca}$ of the different chamber positions (F; F-1; F-2, supplement 1 ) were compared for each species. No significant intra-test $\mathrm{Mg} / \mathrm{Ca}$ variability was detected in $\mathrm{G}$. ruber, $P$. obliquiloculata and G. scitula. Only N. dutertrei shows increasing $\mathrm{Mg} / \mathrm{Ca}$ values towards the final chamber [Figure 6]. An analysis of variance on ranks (Kruskal-Wallis One Way analysis) showed that the differences are significant at the level of $p<0.001$. A pairwise Multiple Comparison Procedure was used to show that all chambers in $N$. dutertrei differ in Mg/Ca (Dunn's Method, $\mathrm{p}<0.05$ ).

\section{$\mathrm{Mn} / \mathrm{Ca}$}

Average test values of $\mathrm{Mn} / \mathrm{Ca}$ in $\mathrm{G}$. ruber $(<8 \mu \mathrm{mol} / \mathrm{mol})$ and $N$. dutertrei are low $(<10 \mu \mathrm{mol} / \mathrm{mol})$ compared to the values recorded for $P$. obliquiloculata $(19.3 \mu \mathrm{mol} / \mathrm{mol}, \mathrm{SE}: 1.7 \mu \mathrm{mol} / \mathrm{mol}, \mathrm{SD}: \pm 11$ $\mu \mathrm{mol} / \mathrm{mol})$ and G. scitula $(40 \mu \mathrm{mol} / \mathrm{mol}$, SE: $1.9 \mu \mathrm{mol} / \mathrm{mol}, \mathrm{SD}: \pm 18 \mu \mathrm{mol} / \mathrm{mol})$. Hence observed concentrations for all species are well above the detection limit for single chamber $\mathrm{Mn} / \mathrm{Ca}$ analyses $(0.42 \mu \mathrm{mol} / \mathrm{mol})$. The maximum offset in average $\mathrm{Mn} / \mathrm{Ca}$ values observed between species ( $G$. ruber versus $G$. scitula) is approximately $33 \mu \mathrm{mol} / \mathrm{mol}$.

There is no significant intra-test variability in $\mathrm{Mn} / \mathrm{Ca}$ observed in $N$. dutertrei or $P$. obliquiloculata for the analysed chambers [Figure 6]. We detect, however, significant intra-test variability in $\mathrm{Mn} / \mathrm{Ca}$ values between successive chambers of $G$. scitula. The average $\mathrm{Mn} / \mathrm{Ca}$ of its final chamber $(F)$ $(19 \pm 10 \mu \mathrm{mol} / \mathrm{mol}$ ) is almost $50 \%$ lower than observed for F-1 and F-2 (both chambers do not significantly differ from each other). We also observed a significant difference in $\mathrm{Mn} / \mathrm{Ca}$ for $\mathrm{G}$. ruber between test chambers $(p=<0.001)$ Lower $\mathrm{Mn} / \mathrm{Ca}(4 \mu \mathrm{mol} / \mathrm{mol}, \mathrm{SD}: \pm 4 \mu \mathrm{mol} / \mathrm{mol})$ are recorded by F-1 compared to F-2 (11 $\mu \mathrm{mol} / \mathrm{mol}, \mathrm{SD}: \pm 8 \mu \mathrm{mol} / \mathrm{mol})$. For further comparison of $\mathrm{Mg} / \mathrm{Ca}$ and $\mathrm{Mn} / \mathrm{Ca}$ values, contrasting eddy and non-eddy conditions we excluded the final chamber (F-0) for all species.

\subsection{Differences in $\mathrm{Me} / \mathrm{Ca}$ between eddy and non-eddy intervals}

\section{$\mathrm{Mg} / \mathrm{Ca}$}

Both G. ruber $\left(\mathrm{N}_{\text {eddy }}=70 ; \mathrm{N}_{\text {non-eddy }}=106\right)$ and $N$. dutertrei $\left(\mathrm{N}_{\text {eddy }}=114 ; \mathrm{N}_{\text {non-eddy }}=152\right)$ have significantly higher Mg/Ca values during eddy compared to non-eddy periods [Figure 5] (G. ruber: $\mathrm{p}=0.004, N$. dutertrei: $\mathrm{p}=<0.001$ ). Although differences in average values are modest, plotting the individual test data in a histogram clearly shows a shift in the relative distribution [Figure 7]. We observe a slightly more positive skewness of $\mathrm{Mg} / \mathrm{Ca}$ distributions for $\mathrm{G}$. ruber, $N$. dutertrei and G. scitula for eddy conditions compared to non-eddy conditions. However a randomization test 
showed that none of the three species showed a significant difference in skewness $(p=0.38, p=$ 0.36 , and $p=0.09$, respectively)

$\mathrm{Mg} / \mathrm{Ca}$ values for $\mathrm{G}$. ruber are lower during non-eddy conditions ( $\mathrm{p}=0.002$ ). Average $\mathrm{Mg} / \mathrm{Ca}$ values for $N$. dutertrei in the F-1 and F-2 chambers are significantly lower ( $p=0.002$ and $p=0.011$, respectively) during non-eddy conditions [Figure 5]. Additional data on F-3 shows no significant difference in $\mathrm{Mg} / \mathrm{Ca}$ between eddy and non-eddy conditions. Generally, there is less $\mathrm{Mg} / \mathrm{Ca}$ variability between chambers during non-eddy conditions compared to eddy conditions. $P$. obliquiloculata and G. scitula do not show significant differences in $\mathrm{Mg} / \mathrm{Ca}$ between chambers (one way ANOVA) between eddy and non-eddy conditions.

\section{$\mathrm{Mn} / \mathrm{Ca}$}

Both G. ruber and N. dutertrei record slightly lower $\mathrm{Mn} / \mathrm{Ca}$ during eddy conditions compared to non-eddy conditions [Figure 5]. However these differences are not significant (Kruskal-Wallis One Way Analysis of Variance on Ranks: G. ruber, $\mathrm{p}=0.439$; N. dutertrei, $\mathrm{p}=0.044$ ) [Figure 5]. In contrast we observe on average higher $\mathrm{Mn} / \mathrm{Ca}$ for $P$. obliquiloculata during eddy conditions (Kruskal-Wallis One Way Analysis of Variance on Ranks, $p<0.001$ ). G. scitula shows no difference in $\mathrm{Mn} / \mathrm{Ca}$ ratios between eddy and non-eddy conditions. There are no significant differences in intra-test trends observed between eddy and non-eddy conditions for any species studied here [Figure 6].

\section{Discussion}

\subsection{Environmental controls on Mg- and Mn-incorporation}

\subsection{1 $\mathrm{Mg} / \mathrm{Ca}$}

Single chamber $\mathrm{Mg} / \mathrm{Ca}$ results show that ratios in $\mathrm{G}$. ruber and $\mathrm{N}$. dutertrei are higher during eddy conditions (Figures 5 and 6), reflecting observed warming at the depths where these species calcify. To test whether differences in temperature stratification between eddy and non-eddy intervals can be reconstructed, we compare inferred calcification depths from multiple species $\mathrm{Mg} / \mathrm{Ca}$ temperatures with in situ mooring data.

We have selected four common species with contrasting depth habitats based on existing literature. Previous studies suggested that G. ruber dwells at or close to the sea surface (e.g. Anand et al., 2003; Field, 2004; Fallet et al., 2010), calcifying in the top $50 \mathrm{~m}$ (e.g. Dekens et al., 2002; Mohtadi et al., 2006; Farmer et al., 2007; Fallet et al., 2010; Birch et al., 2013). 
N. dutertrei is an intermediate deep dwelling species living preferentially in the seasonal thermocline (e.g. Fairbanks et al., 1982; Curry et al., 1983; Eguchi et al., 2003; Farmer et al., 2007), where maximum abundances may coincide with a deep chlorophyll maximum (Fairbanks et al., 1980; Ravelo et al., 1990). Overall living depth is likely within the upper $200 \mathrm{~m}$ (Kroon and Darling, 1995; Farmer et al., 2007). Analyzing inter-chamber $\mathrm{Mg} / \mathrm{Ca}$ variability within single specimen test walls of $N$. dutertreifrom the Timor Sea Eggins et al. (2003) showed that this species recorded temperatures between 12 and $23^{\circ} \mathrm{C}$, implying migration through the entire thermocline. However, the majority of calcification may be limited to a more restricted depth interval. This is suggested by oxygen isotope analyses of $N$. dutertrei in the Indian Ocean (Kiefer et al., 2006), showing a much narrower range within the upper thermocline (40 - 150 meters). Paired Mg/Ca $\delta^{18} \mathrm{O}$ analyses of sediment trap samples from the Mozambique Channel suggest that $N$. dutertrei also calcifies at depths of approximately 80 meters at this location (Fallet et al., 2011).

The species $P$. obliquiloculata is known to inhabit tropical to subtropical water masses (e.g. Tolderlund and Bé, 1971; Wilke et al., 2006, 2009). It was also shown by Ganssen and Sarnthein (1983) that this species thrives in winter periods off NW Africa, when upwelling conditions are prevailing. Its habitat depth has been suggested to be between 0 and 100 meters (Erez and Honjo, 1981; Ravelo and Fairbanks, 1992; Watkins et al., 1996; Cléroux et al., 2008). Other field studies reported somewhat deeper calcification for this species at 120 - 180 meters, based on plankton tows, sediment traps and coretops off NW Africa (Wilke et al., 2009).

The deep dweller G. scitula is non-symbiont bearing and has been shown to inhabit the deeper part of the water column between 0 and 700 meters (Bé et al., 1977; Ortiz et al., 1996; Schiebel and Hemleben, 2000; Itou et al., 2001; Hathorne et al., 2009). A recent study used $\mathrm{Mg} / \mathrm{Ca}$ to suggest a calcification depth of 200 - 300 meters (Fallet et al., 2011).

Culture studies revealed that chamber formation occurs relatively fast and is concentrated in short time intervals (5 - 6 hrs, Bé et al., 1979; every 1-3 days, Bé et al., 1977; Caron et al., 1987; Spero and Lea, 1993; Lea et al., 1999). When chambers are added, a layer of calcite precipitates over pre-existing carbonate, resulting in so-called bilamellar chamber walls (Reiss, 1957). This is reflected by an increase in the thickness of chamber walls and in the length of the ablation profiles towards the older chambers.

Laser ablation inductively coupled plasma mass spectrometry (LA-ICP-MS) was used to quantify intra-specimen variability in $\mathrm{Mg} / \mathrm{Ca}$ in planktonic foraminifera. Part of the observed intra-specimen variability was attributed to seasonal variability in sea surface temperatures. Other factors contributing to intra-specimen variability are, e.g., changes in symbiont activity, carbonate 
chemistry and ontogenetic effects. These ontogenetic effects may influence $\mathrm{Mg} / \mathrm{Ca}$ in two ways: first, formation of a final layer of calcite with relatively low $\mathrm{Mg} / \mathrm{Ca}$ enveloping the whole test at the end of the life cycle potentially results in a trend in trace element incorporation with test size (Marr et al., 2011). And secondly, decreasing $\mathrm{Mg} / \mathrm{Ca}$ values towards the younger chambers of $G$. sacculifer tests are in line with a decreasing contribution of gametogenic calcite to the total calcite with increasing with test size (Sadekov et al., 2008; Wit et al., 2010; Marr et al., 2011; Jonkers et al., 2012). Our Mg/Ca results for $G$. ruber, however, indicate that combining $\mathrm{Mg} / \mathrm{Ca}$ values of $\mathrm{F}-1$ and F-2 chambers does not bias the results. The F-0 chambers do show somewhat deviating values and were, therefore, excluded from further analyses. Since the F-0 chambers also have the thinnest test wall and thus shortest ablation profiles, excluding measurements on the F-0 chamber from the calculations also lowers the observed intra-test variability. Wit et al. (2010) also showed that mean $\mathrm{Mg} / \mathrm{Ca}$ values for $\mathrm{G}$. ruber between the final three chambers differ, but only the offset between the final chamber and the others is significant. In line with the results presented here there was no significant difference in $\mathrm{Mg} / \mathrm{C}$ a values between $\mathrm{F}-1$ and $\mathrm{F}-2$.

$\mathrm{Mg} / \mathrm{Ca}$ results obtained for all species are in line with previously published data and consistent with inferred depth habitats of these species [Figures 2 and 8]. The average $\mathrm{Mg} / \mathrm{Ca}$ value for $G$. ruber, for example, is $5.3 \mathrm{mmol} / \mathrm{mol}$, which corresponds to a seawater temperature of $28^{\circ} \mathrm{C}$, which is in agreement with reconstructed average flux-weighted $\mathrm{Mg} / \mathrm{CaSSTs}$ of $28^{\circ} \mathrm{C}$ for $\mathrm{G}$. ruber (Fallet et al., 2010) for the same trap location. For the other species, inferred calcification temperatures are $22.5^{\circ} \mathrm{C}\left(N\right.$. dutertrei, SD: $\left.\pm 4^{\circ} \mathrm{C}\right), 21.2^{\circ} \mathrm{C}$ (P. obliquiloculata, $\left.S D: \pm 3.1^{\circ} \mathrm{C}\right)$ and $14.4^{\circ} \mathrm{C}$ (G. scitula, $S D: \pm 2.5^{\circ} \mathrm{C}$ ). Both $\mathrm{Mg} / \mathrm{Ca}$ inferred temperatures for $N$. dutertrei and $G$. scitula compare well with flux-weighted $\mathrm{Mg} / \mathrm{Ca}$ temperatures of $23.1^{\circ} \mathrm{C}$ and $15.1^{\circ} \mathrm{C}$, respectively (Fallet et al., 2011C). Additionally, our LA-ICP-MS Mg/Ca values ( $2.6 \mathrm{mmol} / \mathrm{mol}, \mathrm{SD}: \pm 1 \mathrm{mmol} / \mathrm{mol}$ ) of specimens of $N$. dutertrei match LA-ICP-MS measurements from the same species in the SW Indian Ocean (Jonkers et al., 2012), showing consistency of the data.

The error in $\mathrm{Mg} / \mathrm{Ca}$-based reconstructed seawater temperature encompasses analytical uncertainty, the error due to inter-individual variability in $\mathrm{Mg} / \mathrm{Ca}$ (Figure 6) and the uncertainty in calibrating $\mathrm{Mg} / \mathrm{Ca}$ to temperature. The main uncertainty in absolute temperature is related to the calibration error, since both analytical uncertainty and inter specimen variability are largely canceled out by using a large number of individuals (De Nooijer et al., 2014). For a number of planktonic species, including the foraminiferal species used here, uncertainties in the $\mathrm{Mg} / \mathrm{Ca}$ temperature calibration are $\sim 0.02$ for the pre-exponential constant and $\sim 0.003$ for the exponential one (Anand et al., 2003). At a temperature of about $20^{\circ} \mathrm{C}$ this results for both the pre-exponential and exponential constants to a $6 \%$ change in $\mathrm{Mg} / \mathrm{Ca}$, which translates to a $1^{\circ} \mathrm{C}$ temperature 
uncertainty. Still, since we are looking at differences between species rather than absolute temperatures the error related to the uncertainty in the calibration does not affect our results. Uncertainties in the calculated offsets between species will hence be mainly due to true interindividual variability. For down-core applications, when enough specimens are available, using even larger sample sizes and pooling specimens for analyses, could further reduce the error (see section 4.2.3).

Decreasing $\mathrm{Mg} / \mathrm{Ca}$ values when comparing species calcifying from the surface to the thermocline [G. ruber $>N$. dutertrei $\geq P$. obliquiloculata $>G$. scitula], are in line with the hypothesis that the selected species inhabit different depth intervals with increasingly cooler temperatures at depth. Hence, single specimen- or single chamber $\mathrm{Mg} / \mathrm{Ca}$ values record short-term temperature variations at the average depth of calcification. Comparing different planktonic species from sediment trap samples thus potentially allows quantification of the impact of meso-scale scale eddies and the associated changes in the seawater temperature profiles on foraminiferal test chemistry.

\subsection{2 $\mathrm{Mn} / \mathrm{Ca}$}

Both G. ruber and N. dutertrei record lower $\mathrm{Mn}$ concentrations in their calcite $(<10 \mu \mathrm{mol} / \mathrm{mol} \mathrm{Ca})$ compared to $P$. obliquiloculata $(19 \mu \mathrm{mol} / \mathrm{mol}, \mathrm{SD}: \pm 11 \mu \mathrm{mol} / \mathrm{mol})$ and $\mathrm{G}$. scitula $(40 \mu \mathrm{mol} / \mathrm{mol}, \mathrm{SD}$ : $\pm 18 \mu \mathrm{mol} / \mathrm{mol}$ ). $\mathrm{Mn} / \mathrm{Ca}$ for these last two species varies considerably between specimens.

So far, $\mathrm{Mn} / \mathrm{Ca}$ in foraminifera has been used as an indicator for contamination (Boyle, 1983; Lea et al., 2005; Pena et al., 2008). Mn coatings are precipitated after deposition the seafloor due to Mn cycling close to the sediment water interface and are thus absent in specimens derived from sediment trap samples. Also clay minerals can provide a major source for natural contamination for $\mathrm{Mn}$ - and $\mathrm{Mg} / \mathrm{Ca}$ analyses of foraminiferal calcite (Barker et al., 2003), but are often absent in sediment trap samples. Still, as some Mn cycling might have occurred even on these short time scales within the sediment trap cups (although poisoned), we rejected $\mathrm{Mn} / \mathrm{Ca}$ ratios higher than $0.1 \mathrm{mmol} / \mathrm{mol}$ from further analyses (total $n=537$, rejected $=3$; see also Barker et al., 2003 for procedure used). Previously Klinkhammer et al. (2009) showed that the $\mathrm{Mn} / \mathrm{Ca}$ ratio in $\mathrm{G}$. ruber and $N$. dutertrei could be used to reconstruct changes in terrestrial input and oxidation/reduction reactions in the water column during the last $30 \mathrm{kyrs}$. Our study shows that differences in $\mathrm{Mn} / \mathrm{Ca}$ between species can be linked to differences in seawater Mn concentrations in the water column in combination with the different inferred depth habitat preferences of the individual species. Incorporation of $\mathrm{Mn}^{2+}$ from seawater into inorganic calcite scales linearly with dissolved $\mathrm{Mn}^{2+}$ concentration (Franklin and Morse, 1983). Manganese is a redox-sensitive trace metal that 
is more soluble in its reduced $\left(\mathrm{Mn}^{2+}\right)$ than oxidized $\left(\mathrm{Mn}^{4+}\right)$ form. $\mathrm{Mn} / \mathrm{Ca}$ records derived from biogenic carbonate could potentially provide a proxy for dissolved $\mathrm{Mn}^{2+}$ concentrations (Munsel et al., 2010) and thereby reflect redox processes controlling the concentration of this element in seawater. Studies on bivalve shells suggest that intra-shell $\mathrm{Mn} / \mathrm{Ca}$ most likely reflects seasonal variation of seawater $\mathrm{Mn}^{2+}$ concentrations (Freitas et al., 2006; Bougeois et al., 2014) The Mozambique Channel however, is an oligotrophic area in which $\mathrm{Mn}$ concentrations are thus unlikely regulated by changes in redox conditions due to phytoplankton activity. Mn belongs to the scavenged type of trace metals, with highest concentrations at the surface and a relatively uniform distribution in deeper waters. Data on seawater Mn concentrations in the Indian Ocean are sparse but measurements from outside the oxygen minimum zone, generally indicate a surface maximum rapidly decreasing below 100 meters (Morley et al., 1993; Thi Dieu Vu and Sohrin, 2013).

The distribution of $\mathrm{Mn}$ in the water column is often closely coupled to oxygen concentration (Mangini et al., 1990). Mn profiles in the western Indian Ocean show various Mn maxima at depth (Saager et al., 1989) that can be linked to hydrographic features such as Intermediate water originating from the Red Sea which exhibits a strong Mn maximum (4.6 - $6.5 \mathrm{nM}$ ) coinciding with a deep $\mathrm{O}_{2}$ minimum. Oxygen profiles from the water column in the Mozambique Channel show a distinct $\mathrm{O}_{2}$ minimum at about 200 meters below the sea surface [Figure 9]. Below this minimum, oxygen concentrations gradually increase until a depth of about 500 meters where a secondary maximum occurs, after which oxygen concentration decreases towards the sea floor. This oxygen minimum at 200 meters appears to be accompanied by maximum Mn concentrations (Saager et al., 1989) [Figure 9]. We hypothesize that the oxygen depleted conditions at this depth recycle $\mathrm{Mn}^{2+}$ back into solution, supporting incorporation of $\mathrm{Mn}$ into biogenic calcite of species calcifying within this depth range. This is consistent with higher $\mathrm{Mn} / \mathrm{Ca}$ incorporation by $P$. obliquiloculata and especially in $G$. scitula, whereas surface and upper thermocline dwellers $G$. ruber and $N$. dutertrei, thriving in the well oxygenated surface waters, incorporate lower $\mathrm{Mn} / \mathrm{Ca}$. Comparing seawater $\mathrm{Mn}$ with $\mathrm{Mn} / \mathrm{C}$ a ratios of the carbonate tests shows that they all fall close to a $\mathrm{D}_{\mathrm{Mn}}=1$ line, except for $G$. ruber. At the sea surface, where $G$. ruber thrives seawater Mn concentrations are higher than expected based on the Mn incorporated. This might be due to the relatively lower concentration of $\mathrm{Mn}$ available for being incorporated into test carbonate due to the complex speciation of trace metals has a major effect on their biological availability (Bruland et al., 1991). Potentially, multiple species $\mathrm{Mn} / \mathrm{Ca}$ values can hence be used to infer paleo-water column oxygenation. 


\subsection{Inter-species $\mathrm{Mg}$ - and $\mathrm{Mn} / \mathrm{Ca}$ as a proxy for eddies}

\subsection{1 $\mathrm{Mn} / \mathrm{Ca}$ in eddy/non eddy intervals}

Although $\mathrm{Mn} / \mathrm{Ca}$ values of $\mathrm{G}$. ruber and $N$. dutertrei are relatively low, during eddy conditions these values become even lower. In contrast, $\mathrm{Mn} / \mathrm{Ca}$ values for $P$. obliquiloculata are significantly higher during eddy conditions (Kruskal-Wallis One Way Analysis of Variance on Ranks, $\mathrm{p}<0.001$ ). Mn/Ca in G. scitula is not significantly different between eddy and non-eddy conditions. The slightly lower $\mathrm{Mn} / \mathrm{Ca}$ concentrations recorded by $G$. ruber and $N$. dutertrei during eddy conditions, fits the expectation of more oligotrophic conditions during these events (Huggett, 2013). Because of its slightly deeper habitat $P$. obliquiloculata apparently records an increase in dissolved $\mathrm{Mn}$ concentration in seawater during the passing of the eddy. Previous observations in the MC (Swart et al., 2010), showed a deepening of the nutricline and the $\mathrm{O}_{2}$ minimum zone, in an anti-cyclonic eddy compared to a non-eddy condition. This is also evident in the mean oxygen anomaly, showing a positive anomaly in the upper 150 meters (up to $20 \mu \mathrm{M}$ ) and then a sudden decrease to a negative anomaly between 150 and 500 meters [Figure 2 and 8]. This implies that the $\mathrm{Mn}$ peak (at 200 meters, Saager et al., 1989), coinciding with the primary $\mathrm{O}_{2}$ minimum, within the water column would also shift and apparently coincide with the calcification depth of $P$. obliquiloculata. G. scitula does not show a significant shift as it is calcifying already within the zone of high $\mathrm{Mn}^{2+}$ and continues to do so during eddy conditions. Hence foraminiferal trace metal incorporation might simultaneously record isotherm and nutricline movements associated with the passing of an eddy.

\subsubsection{Comparison recorded in-situ temperatures with foraminiferal $\mathrm{Mg} / \mathrm{Ca}$}

Changes in the water column temperature profile in response to a passing eddy in the $\mathrm{MC}$ potentially affect differences in Mg/Ca between different species of planktonic foraminifera. Since eddies mainly affect temperatures at the upper thermocline, comparing $\mathrm{Mg} / \mathrm{Ca}$-based temperatures of thermocline dwellers, such as $N$. dutertrei and $P$. obliquiloculata, with those of either a surface dwelling species such as $G$. ruber, or a deep dwelling species such as $G$. scitula potentially should reflect eddy conditions. Still, such a proxy requires no or limited changes in depth habitat related to hydrographic changes caused by passage of an eddy. For $P$. obliquiloculata we observed a change in depth habitat (constant $\mathrm{Mg} / \mathrm{Ca}$ ) between eddy and noneddy conditions, making it unsuitable for reconstructing changes in thermocline temperatures (Figure 8). Mg/Ca values for $P$. obliquiloculata remain relatively constant between eddy and noneddy conditions, suggesting a change in calcification depth. Comparing the temperature profiles 
from the moorings with the measured $\mathrm{Mg} / \mathrm{Ca}$ values for $P$. obliquiloculata suggests that the mean calcification depth shifts from 80 meters, during non-eddy conditions, to a depth of about 160 meters during eddy conditions. This suggests that this species might be bound to a specific temperature range for optimal living conditions. In contrast, $N$. dutertrei records significantly warmer temperatures when an eddy passes the $\mathrm{MC}$, compared to periods without an eddy (One Way Analysis of Variance, $\mathrm{p}<0.001)$.

The temperature difference between $G$. ruber and $N$. dutertrei is $5.8^{\circ} \mathrm{C}$ during eddy conditions [Figure 10], corresponding to an observed temperature difference between 0 and 115 meters. During non-eddy conditions, the difference in $\mathrm{Mg} / \mathrm{Ca}$-based temperatures between $\mathrm{G}$. ruber and $N$. dutertrei is larger $\left(6.8^{\circ} \mathrm{C}\right)$, although less than expected when assuming a constant calcification depth for these two species. This suggests a slightly shallower calcification depth for $N$. dutertrei (from $\sim 115$ to 90 meters) during non-eddy conditions. Moreover, the temperature recorded by $G$. ruber is also somewhat higher during eddy conditions (one-way Analysis of Variance, $p=0.002$ ). Despite these small changes in calcification depths, overall habitat preferences for $G$. ruber and $N$. dutertrei are relatively constant. The restricted, shallow habitat depth of $G$. ruber is likely related to its associated symbionts (Gastrich, 1987), whereas the living depth of $N$. dutertrei is related to the deep chlorophyll maximum (Fairbanks et al., 1980; Ortiz et al., 1996, Cléroux et al. 2013). Potentially, food availability may restrict foraminiferal species to a certain calcification depth (e.g. Ortiz et al., 1996; Mortyn and Charles, 2003; Cléroux et al., 2009). Irrespective of the underlying mechanism, the recorded $\mathrm{Mg} / \mathrm{Ca}$-based temperatures coincide with a deepening in isotherms during the passing of an eddy. Still, temperature differences based on $\mathrm{Mg} / \mathrm{Ca}$ of $\mathrm{G}$. ruber and $N$. dutertrei from eddy and non-eddy conditions are relatively small and a two-way ANOVA test showed this difference to be not significant $(p=0.166)$.

Alternatively, changes in upper thermocline temperature (i.e. recorded by $\mathrm{Mg} / \mathrm{Ca}$ of $N$. dutertrel) could be contrasted with that of a species dwelling below the thermocline to develop a proxy for eddy activity. The deep dwelling species $G$. scitula has similar Mg/Ca values during eddy and noneddy conditions (Figure 8). Facultative and non-symbiotic species, such as $P$. obliquiloculata and G. scitula, generally are less restricted to light availability and are thus capable of more extensive vertical migration through the water column (Hemleben, 1989). For G. scitula, the lack of an Mg/Ca response to eddy versus non-eddy conditions actually implies a change in calcification depth. Based on the observed similar Mg/Ca values this species changes its calcification depth from 215 meters during non-eddy conditions to 325 meters during eddy conditions. Still, the temperature gradient at the depth $G$. scitula calcifies is small, hence translating into large depth changes. The similar $\mathrm{Mg} / \mathrm{Ca}$ values for $\mathrm{G}$. scitula, comparable to $P$. obliquiloculata, suggest that these planktonic 
foraminifera are passively dragged downward with the isopycnal movement, induced by the passing of an eddy. Comparing the temperature difference between $N$. dutertrei and $G$. scitula, we see a larger offset under eddy conditions $\left(\Delta \mathrm{T}: 9.3^{\circ} \mathrm{C}\right)$ compared to non-eddy conditions $(\Delta \mathrm{T}$ : $6.1^{\circ} \mathrm{C}$ ). This difference in $\mathrm{Mg} / \mathrm{Ca}$ between eddy and non-eddy conditions for $N$. dutertrei and $\mathrm{G}$. scitula is significant (Two-way ANOVA test, $p=0.0015$ ). The inferred difference in temperature offset between the two species during eddy conditions $\left(3.2^{\circ} \mathrm{C}\right)$ matches well with the observed difference at 110 meter of about $3.7^{\circ} \mathrm{C}$. Moreover, using the difference in temperature offset between a thermocline and a deep dweller limits the effects of seasonality, which becomes less with depth (annual difference: $\Delta \mathrm{T}_{0 \mathrm{~m}}: \pm 5^{\circ} \mathrm{C} ; \Delta \mathrm{T}_{200 \mathrm{~m}}: 2.3^{\circ} \mathrm{C} ; \Delta \mathrm{T}_{400 \mathrm{~m}}: 0.6^{\circ} \mathrm{C}$ ).

The difference in calcification temperature, based on $\mathrm{Mg} / \mathrm{Ca}$, between thermocline and subthermocline foraminiferal species provides a promising proxy for reconstructing eddies. The temperature contrast between the upper part of the thermocline and sub-thermocline during eddy and non-eddy conditions is more than $3^{\circ} \mathrm{C}$, comparable to changes in temperature gradients related to eddy occurrences. Potentially, this allows the reconstruction of changes in eddy-intensity over geological time in the proximity of the MC.

\subsubsection{Paleo-application}

Eddies are expressed on a sub-seasonal time scale (Fallet et al., 2011) lasting approximately 6 weeks (Ullgren et al., 2012). On average 5 - 7 eddies pass the MC every year (for the past 10 years; Schouten et al., 2002; Ullgren et al., 2012). Without a clear seasonal pattern in eddy occurrences and no impact of eddy presence on foraminiferal shell fluxes (Fallet et al., 2010; 2011), this implies that approximately $69 \%$ of all planktonic foraminifera arriving at the seafloor in the $\mathrm{MC}$ are produced under eddy-induced conditions. Different conditions prevailing in the past may have resulted in a different frequency of eddies. Even if this resulted in only 1 extra or 1 less eddy per year compared to the current-day frequency, the portion of foraminiferal specimens affected by eddy conditions increases from $69 \%$ to $81 \%$ (or decreases to $58 \%$ ). Although average inter-specific offsets in some cases (as for example between $G$. ruber and $N$. dutertrei) might be limited, determining single specimen $\mathrm{Mg} / \mathrm{Ca}$ also results in significant shifts in the distribution of single specimen Mg/Ca-based temperatures. Histograms of the modern day single specimen $\mathrm{Mg} / \mathrm{Ca}$ distributions comparing eddy and non-eddy conditions already clearly illustrate the shift in distribution of $\mathrm{Mg} / \mathrm{Ca}$ values for $N$. dutertrei [Figure 7]. Since eddy frequency and changes in seasonality both affect average $\mathrm{Mg} / \mathrm{Ca}$ values, these histograms might be used to deconvolve the underlying processes. In view of the observed offset, the difference in $\mathrm{Mg} / \mathrm{Ca}$ values between $\mathrm{G}$. 
scitula and $N$. dutertrei, both impacted much less by seasonality, may well provide a robust proxy for eddy frequency. Moreover, in combination with $\mathrm{Mn} / \mathrm{Ca}$, this proxy might add further constrains for the reconstruction of past water column conditions in the context of eddy frequency.

\section{Conclusions:}

LA-ICP-MS Me/Ca analyses of four species of planktonic foraminifera show that $\mathrm{G}$. ruber and especially $N$. dutertrei Mg/Ca-based temperatures record eddy-induced changes in upper water column stratification. During eddy conditions the thermal gradient between the surface water and the thermocline is reduced whereas the gradient between thermocline and deep water is larger. This is reflected in a reduced difference in the $\mathrm{Mg} / \mathrm{Ca}$ based temperatures between $\mathrm{G}$. ruber and $N$. dutertrei and a larger difference in $\mathrm{Mg} / \mathrm{Ca}$ based temperatures between $N$. dutertrei and $\mathrm{G}$. scitula. Whereas the difference between $G$. ruber and $N$. dutertrei is not statistically significant, the difference between $N$. dutertrei and $G$. scitula is significant. The temperature difference between the two species is larger than $\mathrm{Mg} / \mathrm{Ca}$ calibration-related uncertainties and hence likely to be a proxy suitable for down-core application. Whereas seasonal temperature changes might bias the relatively smaller temperature difference between $G$. ruber and $N$. dutertrei, the difference between $N$. dutertrei and $G$. scitula is more robust. Whereas $G$. ruber and $N$. dutertrei inhabit relatively stable calcification depths, $P$. obliquiloculata and $G$. scitula record similar temperatures during eddy and non-eddy conditions, implying passive or active transport with isopycnal movements induced by passing of an eddy. Additionally, we found that near-surface dwelling G. ruber and shallow thermocline dwelling $N$. dutertrei, inhabit well oxygenated surface waters and show lower $\mathrm{Mn} / \mathrm{Ca}$ values in their tests than the deeper dwelling species. Coinciding with a water column $\mathrm{O}_{2}$ minimum, $P$. obliquiloculata and $G$. scitula record higher $\mathrm{Mn} / \mathrm{Ca}$ values in line with water column variability in dissolved $\mathrm{Mn}$ concentrations. Potentially, combining the analyses of $\mathrm{Mg} / \mathrm{Ca}$ and $\mathrm{Mn} / \mathrm{Ca}$ from multiple species may be used to infer past eddy conditions in the Mozambique Channel.

\section{Acknowledgements}

We gratefully acknowledge the constructive comments of our reviewers, David Lea and one anonymous reviewer as well as the comments by the editor that helped improving the manuscript. We acknowledge funding from the European Commission $7^{\text {th }}$ Framework Marie Curie People program FP7/2007-2013 through funding of the Initial Training Network 'GATEWAYS' (www.gatewaysitn.eu) under the grant number 238512. Furthermore we acknowledge funding from the LOCO programs. Analyses and visualizations of satellite SST used in this paper were produced with the Giovanni online data system, developed and 
maintained by the NASA GES DISC. We thank the chief scientist Herman Ridderinkhof and the crew of the RRV Charles Darwin, RRV Discovery, FS Meteor, RV Pelagia and FS Algoa. Great thanks to Ing. Helen de Waard and Michiel Kienhuis for providing technical support with the trace element analysis at Utrecht University.

\section{APPENDIX A. SUPPLEMENTARY DATA}

Supplementary data associated with this article can be found in S1

\section{References}

Anand, P., Elderfield, H., Conte, M., 2003. Calibration of $\mathrm{Mg} / \mathrm{Ca}$ thermometry in planktonic foraminifera from a sediment trap time series. Paleoceanography 18, 28-31.

Bruland, K.W., Donut, J.R., Hutchins, D.A., 1991. Interactive influences of bioactive trace metals on biological production in oceanic waters. Limnol Ocean. 36, 1555-1577.

Backeberg, B., Reason, C., 2010. A connection between the South Equatorial Current north of Madagascar and Mozambique Channel Eddies. Geophys. Res. Lett. 37, L04604.

Backeberg, B.C., Penven, P., Rouault, M., 2012. Impact of intensified Indian Ocean winds on mesoscale variability in the Agulhas system. Nat. Clim. Change 2, 608-612.

Bakun, A., 2006. Fronts and eddies as key structures in the habitat of marine fish larvae: opportunity, adaptive response and competitive advantage. Sci. Mar. 70, 105-122.

Ballegooyen, R.C., Gründlingh, M.L., Lutjeharms, J.R., 1994. Eddy fluxes of heat and salt from the southwest Indian Ocean into the southeast Atlantic Ocean: A case study. J. Geophys. Res. Oceans 1978-2012 99, 14053-14070.

Barker, S., Greaves, M., Elderfield, H., 2003. A study of cleaning procedures used for foraminiferal Mg/Ca paleothermometry. Geochem. Geophys. Geosystems 4, 8407.

Bé, A.W., 1969. Planktonic foraminifera. Antarct. Map Folio Ser. Am. Geogr. Soc. 9-12.

Bé, A.W., Hemleben, C., Anderson, O.R., Spindler, M., 1979. Chamber formation in planktonic foraminifera. Micropaleontology 294-307.

Bé, A.W., Hemleben, C., Anderson, O.R., Spindler, M., Hacunda, J., Tuntivate-Choy, S., 1977. Laboratory and field observations of living planktonic foraminifera. Micropaleontology 155-179.

Beal, L.M., De Ruijter, W.P.M., Biastoch, A., Zahn, R., 2011. On the role of the Agulhas system in ocean circulation and climate. Nature 472, 429-436. doi:10.1038/nature09983

Bentov, S., Erez, J., 2006. Impact of biomineralization processes on the Mg content of foraminiferal shells: A biological perspective. Geochem. Geophys. Geosystems 7, Q01P08.

Biastoch, A., Böning, C.W., 2013. Anthropogenic impact on Agulhas leakage. Geophys. Res. Lett. 40, 1138-1143. doi:10.1002/grl.50243

Biastoch, A., Böning, C.W., Lutjeharms, J., 2008. Agulhas leakage dynamics affects decadal variability in Atlantic overturning circulation. Nature 456, 489-492.

Biastoch, A., Krauss, W., 1999. The role of mesoscale eddies in the source regions of the Agulhas Current. J. Phys. Oceanogr. 29, 2303-2317.

Birch, H., Coxall, H.K., Pearson, P.N., Kroon, D., O’Regan, M., 2013. Planktonic foraminifera stable isotopes and water column structure: Disentangling ecological signals. Mar. Micropaleontol.

Bougeois, L., de Rafélis, M., Reichart, G.-J., de Nooijer, L.J., Nicollin, F., Dupont-Nivet, G., 2014. A high resolution study of trace elements and stable isotopes in oyster shells to estimate 
Central Asian Middle Eocene seasonality. Chem. Geol. 363, 200-212. doi:10.1016/j.chemgeo.2013.10.037

Boyle, E.A., 1983. Manganese carbonate overgrowths on foraminifera tests. Geochim. Cosmochim. Acta 47, 1815-1819. doi:10.1016/0016-7037(83)90029-7

Brady, H., 1882. Foraminifera in Tizard and Murray's Exploration of the Faroe Channel. Presented at the Proc. Roy. Soc.

Byrne, D.A., Gordon, A.L., Haxby, W.F., 1995. Agulhas eddies: A synoptic view using Geosat ERM data. J. Phys. Oceanogr. 25, 902-917.

Caron, D.A., Faber, W.W., Bé, A.W., 1987. Growth of the spinose planktonic foraminifer Orbulina universa in laboratory culture and the effect of temperature on life processes. J. Mar. Biol. Assoc. U. K. 67, 343-358.

Cléroux, C., Cortijo, E., Anand, P., Labeyrie, L., Bassinot, F., Caillon, N., Duplessy, J.-C., 2008. $\mathrm{Mg} / \mathrm{Ca}$ and $\mathrm{Sr} / \mathrm{Ca}$ ratios in planktonic foraminifera: Proxies for upper water column temperature reconstruction. Paleoceanography 23, PA3214. doi:10.1029/2007pa001505

Cléroux, C., Cortijo, E., Duplessy, J., Zahn, R., 2007. Deep-dwelling foraminifera as thermocline temperature recorders. Geochem. Geophys. Geosystems 8.

Cléroux, C., Lynch-Stieglitz, J., Schmidt, M.W., Cortijo, E., Duplessy, J.-C., 2009. Evidence for calcification depth change of Globorotalia truncatulinoides between deglaciation and Holocene in the Western Atlantic Ocean. Mar. Micropaleontol. 73, 57-61. doi:10.1016/j.marmicro.2009.07.001

Cook, G.S., 1966. NON-TIDAL CIRCULATION IN RHODE ISLAND SOUND. DRIFT BOTTLE AND SEA-BED DRIFTER EXPERIMENTS, 1962-1963.

Cronin, M., Watts, D.R., 1996. Eddy-mean flow interaction in the Gulf Stream at 68 W. Part I: Eddy energetics. J. Phys. Oceanogr. 26, 2107-2131.

Curry, W.B., Thunell, R.C., Honjo, S., 1983. Seasonal changes in the isotopic composition of planktonic foraminifera collected in Panama Basin sediment traps. Earth Planet. Sci. Lett. 64, 33-43. doi:10.1016/0012-821X(83)90050-X

D’ Orbigny, A., 1839. Foraminifères. Hist. Phys. Polit. Nat. Lî Cuba Bertrand Paris.

De Nooijer, L.J., Hathorne, E.C., Reichart, G.J., Langer, G., Bijma, J., 2014. Variability in calcitic $\mathrm{Mg} / \mathrm{Ca}$ and $\mathrm{Sr} / \mathrm{Ca}$ ratios in clones of the benthic foraminifer Ammonia tepida. Mar. Micropaleontol. 107, 32-43. doi:10.1016/j.marmicro.2014.02.002

De Ruijter, W., Aken, H., Beier, E., Lutjeharms, J., Matano, R., Schouten, M., 2004. Eddies and dipoles around South Madagascar: formation, pathways and large-scale impact. Deep Sea Res. Part Oceanogr. Res. Pap. 51, 383-400.

De Ruijter, W., Van Leeuwen, P., Weijer, W., Biastoch, A., Drijfhout, S., Lutjeharms, J., Matano, R., Pichevin, T., 1999. Indian-Atlantic interocean exchange- Dynamics, estimation and impact. J. Geophys. Res. 104, 20,885-20,910.

De Ruijter, W.P., Ridderinkhof, H., Lutjeharms, J.R., Schouten, M.W., Veth, C., 2002. Observations of the flow in the Mozambique Channel. Geophys. Res. Lett. 29, 1502.

Dekens, P.S., Lea, D.W., Pak, D.K., Spero, H.J., 2002. Core top calibration of Mg/Ca in tropical foraminifera: Refining paleotemperature estimation. Geochem. Geophys. Geosystems 3, 1022.

Dueñas-Bohórquez, A., da Rocha, R.E., Kuroyanagi, A., Bijma, J., Reichart, G.-J., 2009. Effect of salinity and seawater calcite saturation state on $\mathrm{Mg}$ and $\mathrm{Sr}$ incorporation in cultured planktonic foraminifera. Mar. Micropaleontol. 73, 178-189. doi:10.1016/j.marmicro.2009.09.002

Dueñas-Bohórquez, A., Raitzsch, M., de Nooijer, L.J., Reichart, G.-J., 2011. Independent impacts of calcium and carbonate ion concentration on $\mathrm{Mg}$ and $\mathrm{Sr}$ incorporation in cultured benthic foraminifera. Mar. Micropaleontol. 81, 122-130.

doi:10.1016/j.marmicro.2011.08.002 
Durgadoo, J.V., Loveday, B.R., Reason, C.J., Penven, P., Biastoch, A., 2013. Agulhas leakage predominantly responds to the Southern Hemisphere Westerlies. J. Phys. Oceanogr. 43, 2113-2131.

Eguchi, N.O., Ujiié, H., Kawahata, H., Taira, A., 2003. Seasonal variations in planktonic foraminifera at three sediment traps in the subarctic, transition and subtropical zones of the central North Pacific Ocean. Mar. Micropaleontol. 48, 149-163.

Elderfield, H., Vautravers, M., Cooper, M., 2002. The relationship between shell size and Mg/Ca, $\mathrm{Sr} / \mathrm{Ca}, \delta 18 \mathrm{O}$, and $\delta 13 \mathrm{C}$ of species of planktonic foraminifera. Geochem. Geophys. Geosystems 3, 1-13.

Erez, J., Honjo, S., 1981. Comparison of isotopic composition of planktonic foraminifera in plankton tows, sediment traps and sediments. Palaeogeogr. Palaeoclimatol. Palaeoecol. 33, 129-156. doi:10.1016/0031-0182(81)90035-3

Fairbanks, R.G., Sverdlove, M., Free, R., Wiebe, P.H., Bé, A.W., 1982. Vertical distribution and isotopic fractionation of living planktonic foraminifera from the Panama Basin. Nature 298, 841-844.

Fairbanks, R.G., Wiebe, P.H., Bé, A.W., 1980. Vertical distribution and isotopic composition of living planktonic foraminifera in the western North Atlantic. Science 207, 61-63.

Fallet, U., Boer, W., van Assen, C., Greaves, M., Brummer, G.-J.A., 2009. A novel application of wet oxidation to retrieve carbonates from large organic-rich samples for ocean-climate research. Geochem Geophys Geosyst 10, Q08004. doi:10.1029/2009gc002573

Fallet, U., Brummer, G.-J., Zinke, J., Vogels, S., Ridderinkhof, H., 2010. Contrasting seasonal fluxes of planktonic foraminifera and impacts on paleothermometry in the Mozambique Channel upstream of the Agulhas Current. Paleoceanography 25, PA4223. doi:10.1029/2010pa001942

Fallet, U., Ullgren, J.E., Castañeda, I.S., van Aken, H.M., Schouten, S., Ridderinkhof, H., Brummer, G.-J.A., 2011a. Contrasting variability in foraminiferal and organic paleotemperature proxies in sedimenting particles of the Mozambique Channel (SW Indian Ocean). Geochim. Cosmochim. Acta 75, 5834-5848. doi:10.1016/j.gca.2011.08.009

Fallet, U., Ullgren, J.E., Castañeda, I.S., van Aken, H.M., Schouten, S., Ridderinkhof, H., Brummer, G.-J.A., 2011b. Contrasting variability in foraminiferal and organic paleotemperature proxies in sedimenting particles of the Mozambique Channel (SW Indian Ocean). Geochim. Cosmochim. Acta 75, 5834-5848. doi:10.1016/j.gca.2011.08.009

Fallet, U., Ullgren, J.E., Castañeda, I.S., van Aken, H.M., Schouten, S., Ridderinkhof, H., Brummer, G.-J.A., 2011c. Contrasting variability in foraminiferal and organic paleotemperature proxies in sedimenting particles of the Mozambique Channel (SW Indian Ocean). Geochim. Cosmochim. Acta 75, 5834-5848. doi:10.1016/j.gca.2011.08.009

Farmer, E.C., Kaplan, A., de Menocal, P.B., Lynch-Stieglitz, J., 2007. Corroborating ecological depth preferences of planktonic foraminifera in the tropical Atlantic with the stable oxygen isotope ratios of core top specimens. Paleoceanography 22.

Field, D.B., 2004. Variability in vertical distributions of planktonic foraminifera in the California Current: Relationships to vertical ocean structure. Paleoceanography 19.

Franklin, M.L., Morse, J.W., 1983. The interaction of manganese (II) with the surface of calcite in dilute solutions and seawater. Mar. Chem. 12, 241-254.

Freitas, P.S., Clarke, L.J., Kennedy, H., Richardson, C.A., Abrantes, F., 2006. Environmental and biological controls on elemental $(\mathrm{Mg} / \mathrm{Ca}, \mathrm{Sr} / \mathrm{Ca}$ and $\mathrm{Mn} / \mathrm{Ca})$ ratios in shells of the king scallop $<$ i $>$ Pecten maximus. Geochim. Cosmochim. Acta 70, 5119-5133.

Friedrich, O., Schiebel, R., Wilson, P.A., Weldeab, S., Beer, C.J., Cooper, M.J., Fiebig, J., 2012. Influence of test size, water depth, and ecology on $\mathrm{Mg} / \mathrm{Ca}, \mathrm{Sr} / \mathrm{Ca}, \delta 18 \mathrm{O}$ and $\delta 13 \mathrm{C}$ in nine 
modern species of planktic foraminifers. Earth Planet. Sci. Lett. 319-320, 133-145. doi:10.1016/j.epsl.2011.12.002

Fu, L.-L., Chelton, D.B., Le Traon, P.-Y., Morrow, R., 2010. Eddy dynamics from satellite altimetry. Oceanography 23, 14-25.

Ganssen, G., Sarnthein, M., 1983. Stable-Isotope Composition of Foraminifers: The Surface and Bottom Water Record of Coastal Upwelling, in: Suess, E., Thiede, J. (Eds.), Coastal Upwelling Its Sediment Record, NATO Conference Series. Springer US, pp. 99-121.

Gastrich, M.D., 1987. Ultrastructure of a New Intracellular Symbiotic Alga Found Within Planktonic Foraminifera1. J. Phycol. 23, 623-632. doi:10.1111/j.15298817.1987.tb04215.x

Gordon, A., 1986. Interocean exchange of thermocline water. J Geophys Res 91, 5037-5046.

Gordon, A.L., Weiss, R.F., Smethie, W.M., Warner, M.J., 1992. Thermocline and intermediate water communication between the South Atlantic and Indian Oceans. J. Geophys. Res. Oceans 1978-2012 97, 7223-7240.

Gründlingh, M.L., 1995. Tracking eddies in the southeast Atlantic and southwest Indian oceans with TOPEX/POSEIDON. J. Geophys. Res. 100, 24977-24,986.

Harlander, U., Ridderinkhof, H., Schouten, M., De Ruijter, W., 2009. Long-term observations of transport, eddies, and Rossby waves in the Mozambique Channel. J Geophys Res 114.

Hathorne, E., Alard, O., James, R., Rogers, N., 2003. Determination of intratest variability of trace elements in foraminifera by laser ablation inductively coupled plasma-mass spectrometry. Geochem. Geophys. Geosystems 4.

Hathorne, E.C., James, R.H., Lampitt, R.S., 2009. Environmental versus biomineralization controls on the intratest variation in the trace element composition of the planktonic foraminifera G. inflata and G. scitula. Paleoceanography 24, PA4204. doi:10.1029/2009pa001742

Hemleben, C., Erson, O.R., Berthold, W., Spindler, M., 1986. Calcification and chamber formation in foraminifera - a brief overview.

Hemleben, C., Spindler, M., Anderson, O., 1989. Modern planktonic foraminifera. Springer, Berlin, 363 pp. Home| About ePIC| Impressum| Deutsch Browse Research divisions Research programm Document types Research platform Reports on Polar and Marine Research" Polarforschung" WDC-Mare" Publication list [PDF].

Huang, K., You, C., Lin, H., Shieh, Y., 2008. In situ calibration of Mg/Ca ratio in planktonic foraminiferal shell using time series sediment trap: A case study of intense dissolution artifact in the South China Sea. Geochem. Geophys. Geosystems 9.

Huggett, J.A., 2013. Mesoscale distribution and community composition of zooplankton in the Mozambique Channel. Deep Sea Res. Part II Top. Stud. Oceanogr.

Itou, M., Ono, T., Oba, T., Noriki, S., 2001. Isotopic composition and morphology of living< i> Globorotalia scitula: a new proxy of sub-intermediate ocean carbonate chemistry? Mar. Micropaleontol. 42, 189-210.

Jochum, K.P., Weis, U., Stoll, B., Kuzmin, D., Yang, Q., Raczek, I., Jacob, D.E., Stracke, A., Birbaum, K., Frick, D.A., Günther, D., Enzweiler, J., 2011. Determination of Reference Values for NIST SRM 610-617 Glasses Following ISO Guidelines. Geostand. Geoanalytical Res. 35, 397-429. doi:10.1111/j.1751-908X.2011.00120.x

Jonkers, L., de Nooijer, L., Reichart, G., Zahn, R., Brummer, G., 2012. Encrustation and trace element composition of Neogloboquadrina dutertrei assessed from single chamber analyses, implications for paleotemperature estimates. Biogeosciences 9, 4851-4860.

Kiefer, T., McCave, I.N., Elderfield, H., 2006. Antarctic control on tropical Indian Ocean sea surface temperature and hydrography. Geophys. Res. Lett. 33.

Kolasinski, J., Kaehler, S., Jaquemet, S., 2012. Distribution and sources of particulate organic matter in a mesoscale eddy dipole in the Mozambique Channel (south-western Indian Ocean): Insight from C and N stable isotopes. J. Mar. Syst. 
Kroon, D., Darling, K., 1995. Size and upwelling control of the stable isotope composition of Neogloboquadrina dutertrei (d'Orbigny), Globigerinoides ruber (d'Orbigny) and Globigerina bulloides d'Orbigny; examples from the Panama Basin and Arabian Sea. J. Foraminifer. Res. 25, 39-52.

Kuroyanagi, A., Kawahata, H., 2004. Vertical distribution of living planktonic foraminifera in the seas around Japan. Mar. Micropaleontol. 53, 173-196.

Lamont, T., Barlow, R., Morris, T., van den Berg, M., 2013. Characterisation of mesoscale features and phytoplankton variability in the Mozambique Channel. Deep Sea Res. Part II Top. Stud. Oceanogr.

Lea, D.W., Mashiotta, T.A., Spero, H.J., 1999. Controls on magnesium and strontium uptake in planktonic foraminifera determined by live culturing. Geochim. Cosmochim. Acta 63, 2369-2379.

Lea, D.W., Pak, D.K., Paradis, G., 2005. Influence of volcanic shards on foraminiferal Mg/Ca in a core from the Galápagos region. Geochem. Geophys. Geosystems 6, Q11P04. doi:10.1029/2005GC000970

Loncaric, N., Peeters, F.J.C., Kroon, D., Brummer, G.J.A., 2006. Oxygen isotope ecology of recent planktic foraminifera at the central Walvis Ridge (SE Atlantic). Paleoceanography $21,3009$.

Loncaric, N., van Iperen, J., Kroon, D., Brummer, G.J.A., 2007. Seasonal export and sediment preservation of diatomaceous, foraminiferal and organic matter mass fluxes in a trophic gradient across the SE Atlantic. Prog. Oceanogr. 73, 27-59.

Lutjeharms, J., Catzel, R., Valentine, H., 1989. Eddies and other boundary phenomena of the Agulhas Current. Cont. Shelf Res. 9, 597-616.

Mackas, D., Tsurumi, M., Galbraith, M., Yelland, D., 2005. Zooplankton distribution and dynamics in a North Pacific Eddy of coastal origin: II. Mechanisms of eddy colonization by and retention of offshore species. Deep Sea Res. Part II Top. Stud. Oceanogr. 52, 1011-1035.

Mangini, A., Eisenhauer, A., Walter, P., 1990. Response of manganese in the ocean to the climatic cycles in the Quaternary. Paleoceanography 5, 811-821. doi:10.1029/PA005i005p00811

Marr, J.P., Baker, J.A., Carter, L., Allan, A.S., Dunbar, G.B., Bostock, H.C., 2011. Ecological and temperature controls on $\mathrm{Mg} / \mathrm{Ca}$ ratios of Globigerina bulloides from the southwest Pacific Ocean. Paleoceanography 26.

Martin, A.P., Richards, K.J., 2001. Mechanisms for vertical nutrient transport within a North Atlantic mesoscale eddy. Deep Sea Res. Part II Top. Stud. Oceanogr. 48, 757-773.

McGillicuddy, D., Robinson, A., Siegel, D., Jannasch, H., Johnson, R., Dickey, T., McNeil, J., Michaels, A., Knap, A., 1998. Influence of mesoscale eddies on new production in the Sargasso Sea. Nature 394, 263-266.

Mensa, J.A., Garraffo, Z., Griffa, A., Özgökmen, T.M., Haza, A., Veneziani, M., 2013. Seasonality of the submesoscale dynamics in the Gulf Stream region. Ocean Dyn. 63, 923-941.

Mohtadi, M., Hebbeln, D., Nuñez Ricardo, S., Lange, C.B., 2006. El Niño-like pattern in the Pacific during marine isotope stages (MIS) 13 and 11? Paleoceanography 21.

Morley, N.H., Statham, P.J., Burton, J.D., 1993. Dissolved trace metals in the southwestern Indian Ocean. Deep Sea Res. Part Oceanogr. Res. Pap. 40, 1043-1062. doi:10.1016/0967-0637(93)90089-L

Mortyn, P.G., Charles, C.D., 2003. Planktonic foraminiferal depth habitat and $\delta 180$ calibrations: Plankton tow results from the Atlantic sector of the Southern Ocean. Paleoceanography 18, 1037. doi:10.1029/2001PA000637

Munsel, D., Kramar, U., Dissard, D., Nehrke, G., Berner, Z., Bijma, J., Reichart, G.-J., Neumann, T., 2010. Heavy metal incorporation in foraminiferal calcite: results from multi-element 
enrichment culture experiments with Ammonia tepida. Biogeosciences 7, 2339-2350. doi:10.5194/bg-7-2339-2010

New, A., Alderson, S., Smeed, D., Stansfield, K., 2007. On the circulation of water masses across the Mascarene Plateau in the South Indian Ocean. Deep Sea Res. Part Oceanogr. Res. Pap. 54, 42-74.

Ni, Y., Foster, G.L., Bailey, T., Elliott, T., Schmidt, D.N., Pearson, P., Haley, B., Coath, C., 2007. A core top assessment of proxies for the ocean carbonate system in surface-dwelling foraminifers. Paleoceanography 22.

Nürnberg, D., Bijma, J., Hemleben, C., 1996. Assessing the reliability of magnesium in foraminiferal calcite as a proxy for water mass temperatures. Geochim. Cosmochim. Acta 60, 803-814. doi:10.1016/0016-7037(95)00446-7

Ortiz, J., Mix, A., Rugh, W., Watkins, J., Collier, R., 1996. Deep-dwelling planktonic foraminifera of the northeastern Pacific Ocean reveal environmental control of oxygen and carbon isotopic disequilibria. Geochim. Cosmochim. Acta 60, 4509-4523.

Owen, R.W., 1981. Fronts and eddies in the sea: mechanisms, interactions and biological effects. Anal. Mar. Ecosyst. 197-233.

Parker, W.K., Jones, T.R., Bailey, J., Pourtales, F., 1865. On some foraminifera from the north Atlantic and Arctic Oceans, including Davis Straits and Baffin's Bay. Philos. Trans. R. Soc. Lond. 155, 325-441.

Peeters, F., Acheson, R., Brummer, G., De Ruijter, W., Schneider, R., Ganssen, G., Ufkes, E., Kroon, D., 2004. Vigorous exchange between the Indian and Atlantic oceans at the end of the past five glacial periods. Nature 430, 661-665.

Pena, L., Cacho, I., Calvo, E., Pelejero, C., Eggins, S., Sadekov, A., 2008. Characterization of contaminant phases in foraminifera carbonates by electron microprobe mapping. Geochem. Geophys. Geosystems 9.

Pflaumann, U., Jian, Z., 1999. Modern distribution patterns of planktonic foraminifera in the South China Sea and western Pacific: a new transfer technique to estimate regional seasurface temperatures. Mar. Geol. 156, 41-83.

Ravelo, A., Fairbanks, R., 1992. Oxygen isotopic composition of multiple species of planktonic foraminifera: Recorders of the modern photic zone temperature gradient. Paleoceanography 7, 815-831.

Ravelo, A., Fairbanks, R., Philander, S., 1990. Reconstructing tropical Atlantic hydrography using planktontic foraminifera and an ocean model. Paleoceanography 5, 409-431.

Reichart, G.-J., Jorissen, F., Anschutz, P., Mason, P.R.D., 2003. Single foraminiferal test chemistry records the marine environment. Geology 31, 355-358. doi:10.1130/00917613(2003)031<0355:SFTCRT>2.0.CO;2

Ridderinkhof, H., Van der Werf, P., Ullgren, J., Van Aken, H., Van Leeuwen, P., De Ruijter, W., 2010. Seasonal and interannual variability in the Mozambique Channel from moored current observations. J. Geophys. Res. 115, C06010/1-C06010/18.

Rosenthal, Y., Boyle, E.A., Slowey, N., 1997. Temperature control on the incorporation of magnesium, strontium, fluorine, and cadmium into benthic foraminiferal shells from Little Bahama Bank: Prospects for thermocline paleoceanography. Geochim. Cosmochim. Acta 61, 3633-3643.

Rosenthal, Y., Lohmann, G., Lohmann, K., Sherrell, R., 2000. Incorporation and preservation of $\mathrm{Mg}$ in Globigerinoides sacculifer: Implications for reconstructing the temperature and $180 / 160$ of seawater. Paleoceanography 15, 135-145.

Saager, P.M., De Baar, H.J.W., Burkill, P.H., 1989. Manganese and iron in Indian Ocean waters. Geochim. Cosmochim. Acta 53, 2259-2267. doi:10.1016/0016-7037(89)90348-7

Sabarros, P.S., Ménard, F., Lévénez, J.-J., Tew-Kai, E., Ternon, J.-F., 2009. Mesoscale eddies influence distribution and aggregation patterns of micronekton in the Mozambique Channel. Mar. Ecol. Prog. Ser. 395, 101-107. 
Sadekov, A., Eggins, S.M., De Deckker, P., Kroon, D., 2008. Uncertainties in seawater thermometry deriving from intratest and intertest $\mathrm{Mg} / \mathrm{Ca}$ variability in Globigerinoides ruber. Paleoceanography 23.

Sallée, J., Morrow, R., Speer, K., 2008. Eddy heat diffusion and Subantarctic Mode Water formation. Geophys. Res. Lett. 35.

Schiebel, R., Hemleben, C., 2000. Interannual variability of planktic foraminiferal populations and test flux in the eastern North Atlantic Ocean (JGOFS). Deep Sea Res. Part II Top. Stud. Oceanogr. 47, 1809-1852.

Schouten, M., De Ruijter, W., Van Leeuwen, P., Dijkstra, H., 2002. An oceanic teleconnection between the equatorial and southern Indian Ocean. Geophys. Res. Lett. 29, 1812.

Schouten, M.W., de Ruijter, W.P.M., van Leeuwen, P.J., 2002. Upstream control of Agulhas Ring shedding. J Geophys Res 107, 3109-3120.

Schouten, M.W., de Ruijter, W.P.M., van Leeuwen, P.J., Ridderinkhof, H., 2003. Eddies and variability in the Mozambique Channel. Deep Sea Res. Part II Top. Stud. Oceanogr. 50, 1987-2003. doi:10.1016/s0967-0645(03)00042-0

Send, U., Font, J., Krahmann, G., Millot, C., Rhein, M., Tintoré, J., 1999. Recent advances in observing the physical oceanography of the western Mediterranean Sea. Prog. Oceanogr. 44, 37-64.

Spero, H.J., Lea, D.W., 1993. Intraspecific stable isotope variability in the planktic foraminifera< is Globigerinoides sacculifer: Results from laboratory experiments. Mar. Micropaleontol. 22, 221-234.

Spero, H.J., Mielke, K.M., Kalve, E.M., Lea, D.W., Pak, D.K., 2003. Multispecies approach to reconstructing eastern equatorial Pacific thermocline hydrography during the past 360 kyr. Paleoceanography 18.

Swallow, J., Fieux, M., Schott, F., 1988. The boundary currents east and north of Madagascar: 1. Geostrophic currents and transports. J. Geophys. Res. Oceans 1978-2012 93, 49514962.

Takahashi, K., Be, A.W., 1984. Planktonic foraminifera: factors controlling sinking speeds. Deep Sea Res. Part Oceanogr. Res. Pap. 31, 1477-1500.

Thi Dieu Vu, H., Sohrin, Y., 2013. Diverse stoichiometry of dissolved trace metals in the Indian Ocean. Sci. Rep. 3. doi:10.1038/srep01745

Tolderlund, D.S., Bé, A.W., 1971. Seasonal distribution of planktonic foraminifera in the western North Atlantic. Micropaleontology 297-329.

Ullgren, J., van Aken, H., Ridderinkhof, H., de Ruijter, W., 2012. The hydrography of the Mozambique Channel from six years of continuous temperature, salinity, and velocity observations. Deep Sea Res. Part Oceanogr. Res. Pap.

Watkins, J.M., Mix, A.C., Wilson, J., 1996. Living planktic foraminifera: tracers of circulation and productivity regimes in the central equatorial Pacific. Deep Sea Res. Part II Top. Stud. Oceanogr. 43, 1257-1282.

Weijer, W., De Ruijter, W.P., Dijkstra, H.A., 2001. Stability of the Atlantic overturning circulation: Competition between Bering Strait freshwater flux and Agulhas heat and salt sources. J. Phys. Oceanogr. 31, 2385-2402.

Weijer, W., De Ruijter, W.P.., Sterl, A., Drijfhout, S.S., 2002. Response of the Atlantic overturning circulation to South Atlantic sources of buoyancy. Glob. Planet. Change 34, 293-311. doi:10.1016/S0921-8181(02)00121-2

Wilke, I., Bickert, T., Peeters, F.J.C., 2006. The influence of seawater carbonate ion concentration [CO32-] on the stable carbon isotope composition of the planktic foraminifera species Globorotalia inflata. Mar. Micropaleontol. 58, 243-258. doi:10.1016/j.marmicro.2005.11.005 
Wilke, I., Meggers, H., Bickert, T., 2009. Depth habitats and seasonal distributions of recent planktic foraminifers in the Canary Islands region $\left(29^{\circ} \mathrm{N}\right)$ based on oxygen isotopes.

Deep Sea Res. Part Oceanogr. Res. Pap. 56, 89-106. doi:10.1016/j.dsr.2008.08.001

Wit, J., Reichart, G., A Jung, S., Kroon, D., 2010. Approaches to unravel seasonality in sea surface temperatures using paired single-specimen foraminiferal $\delta 180$ and $\mathrm{Mg} / \mathrm{Ca}$ analyses. Paleoceanography 25.

Wyrtki, K., 1973. Physical oceanography of the Indian Ocean, in: The Biology of the Indian Ocean. Springer, pp. 18-36.

Xiu, P., Palacz, A.P., Chai, F., Roy, E.G., Wells, M.L., 2011. Iron flux induced by Haida eddies in the Gulf of Alaska. Geophys. Res. Lett. 38.
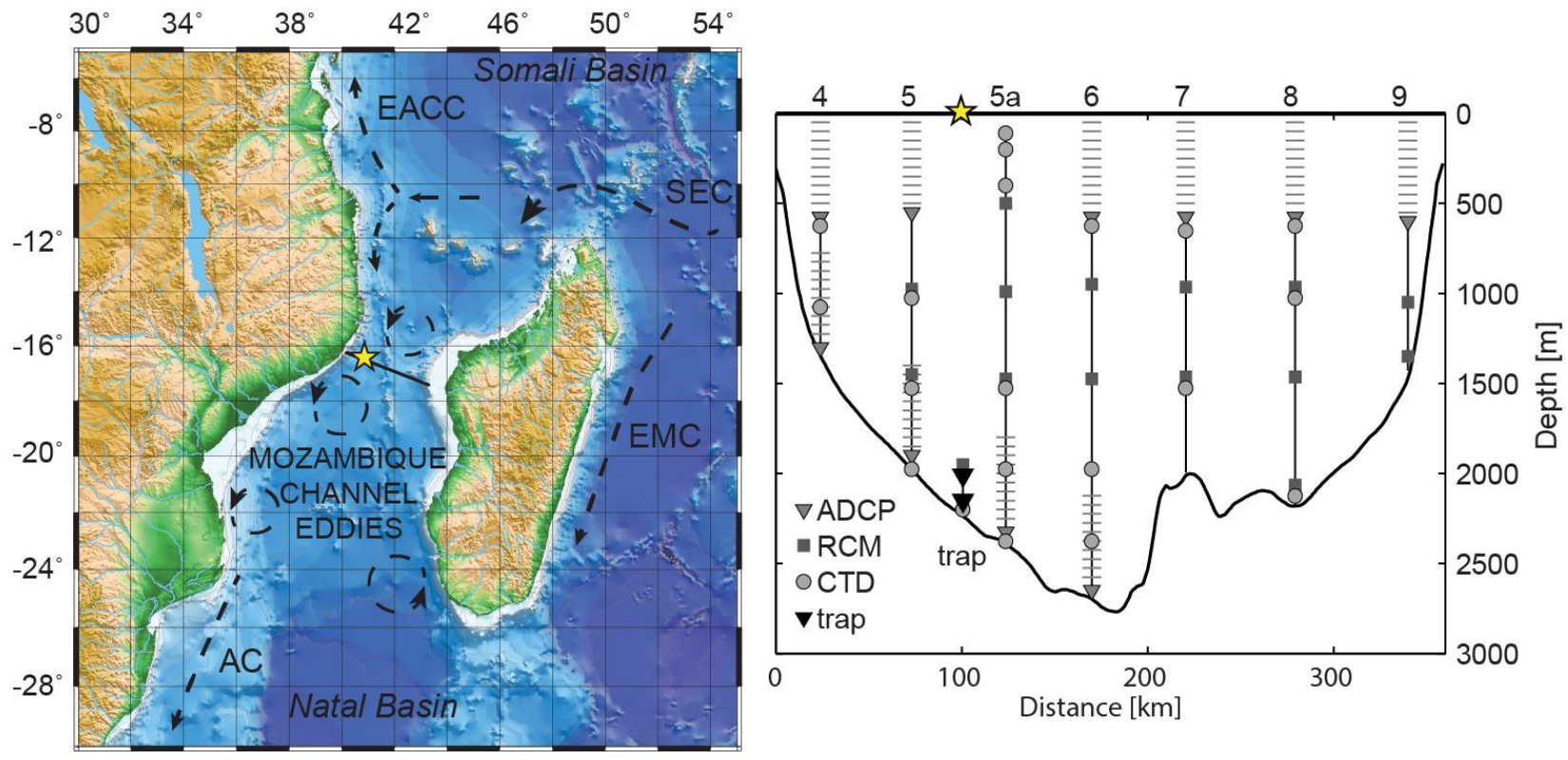

Figure 1: Overview map of southwestern Indian Ocean and location of the sediment trap (indicated by yellow star) and the line of mooring deployments. The mooring array is shown in detail on the right. The yellow star indicates the location of the trap within the mooring array. EACC: East African Coastal Current, SEC: South Equatorial Current, AC: Agulhas Current, EMC: East Madagascar Current, star: sediment trap location. 


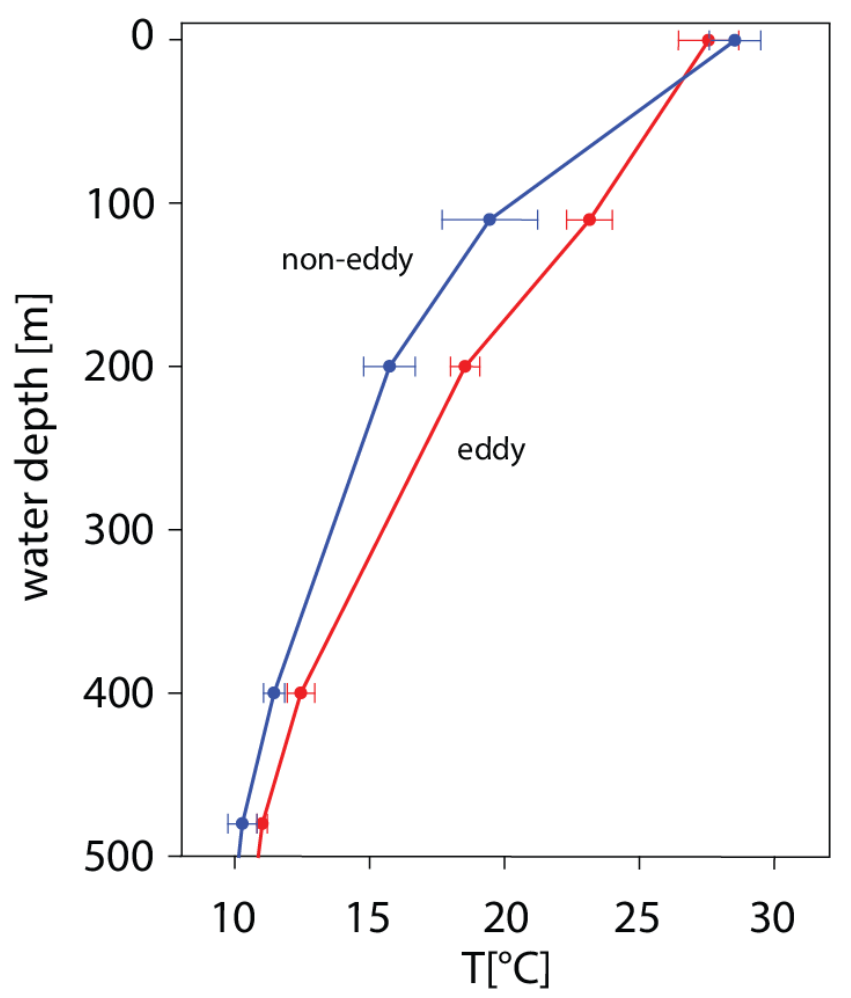

Figure 2: Temperature profiles for the water column in the Mozambique Channel. Indicated in red for eddy and in blue for non-eddy conditions, derived from averaging the observed $\mathrm{T}\left[{ }^{\circ} \mathrm{C}\right]$ profiles during 3 individual eddy intervals and 3 non-eddy intervals. Data is plotted for the upper 500 meters only.

Figure 3: Lagrangian back trajectory results. For the experiment 10000 particles are released at $40.85^{\circ} \mathrm{E} ; 16.71^{\circ} \mathrm{S}$ and from $2100 \mathrm{~m}$ water depth. Assuming $1 \mathrm{~cm} / \mathrm{s}$ sinking speed, particles placed back at 25 meters, 50 meters and 150 meters. The particles reach the surface after $\sim 3$ days. Graph shows the distribution of particles per $0.5 \times 0.5$ degree box after 6 weeks of advection (assuming an average lifespan approximation of foraminifera) after they surfaced at their respective depths. Warmer colors can be interpreted as a more probable location of foraminifera 6 weeks before they started to sink. Sediment trap location is indicated with a black cross. 

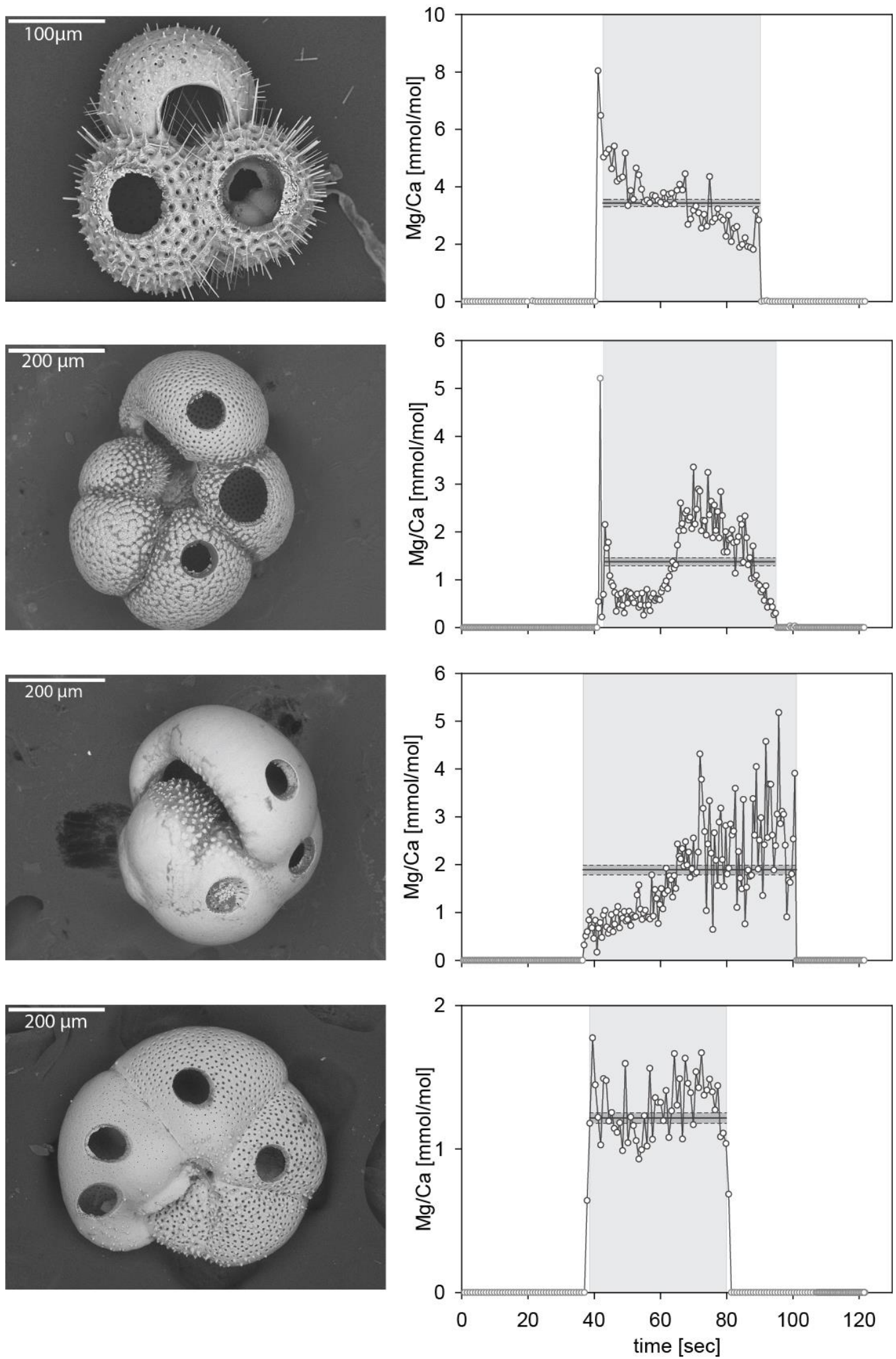

Figure 4: Scanning electron microscope (SEM) pictures of G. ruber, N. dutertrei, P. obliquiloculata and $G$. scitula, showing the laser ablation craters created during the trace metal analyses. On the right panel, typical LA-ICP-MS Mg/Ca profiles are shown. Circles within grey area are used for integration of $\mathrm{Me} / \mathrm{Ca}$ concentration calculations. 

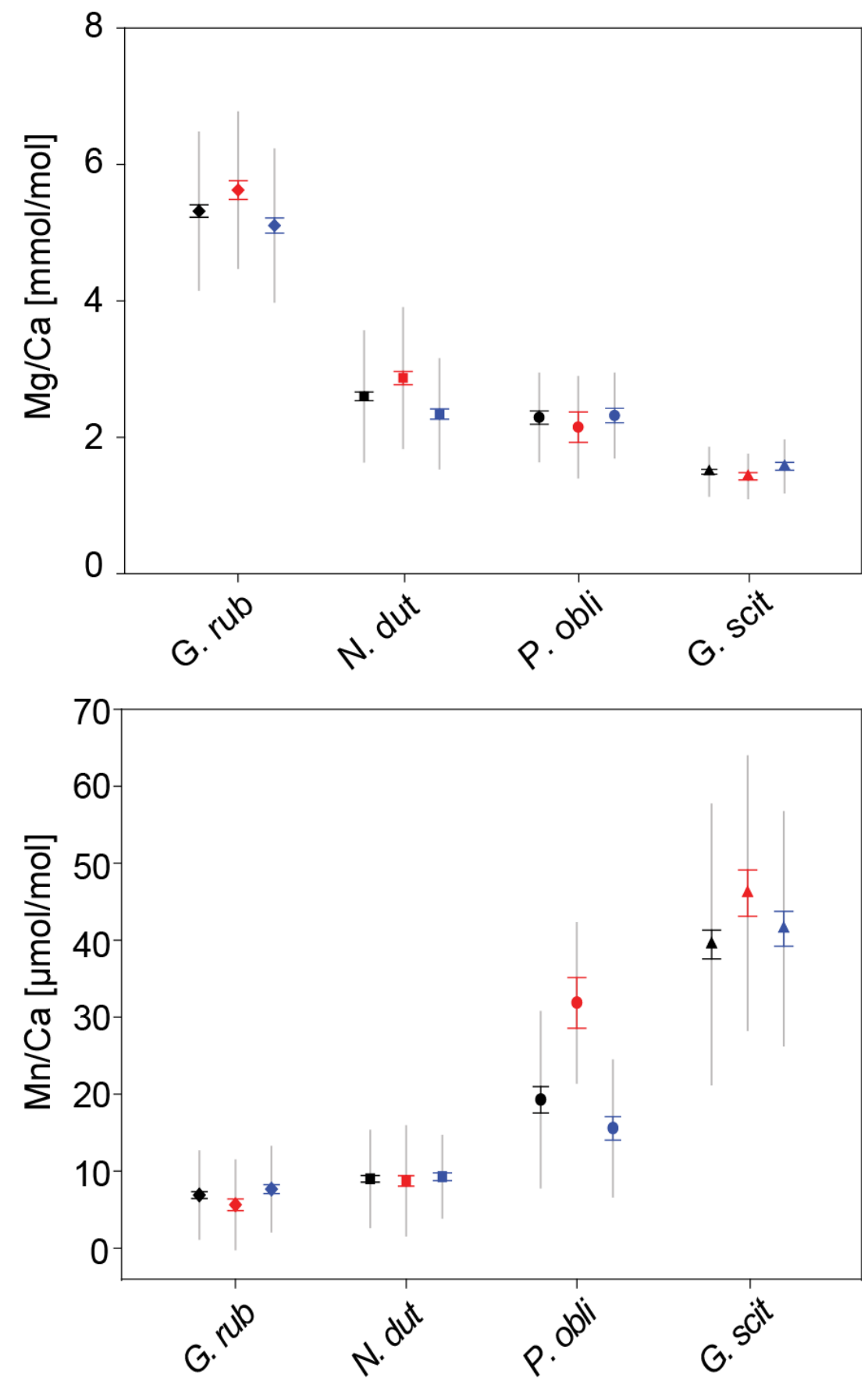

Figure 5: Averaged $\mathrm{Mg} / \mathrm{Ca}(\mathrm{a})$ and $\mathrm{Mn} / \mathrm{Ca}$ (b) values (black), based on all specimen analyzed, excluding outliers based on two times standard deviation (SD) of the entire population. In red data for eddy conditions. Blue symbols correspond to non-eddy conditions. Error bars indicate standard error, extended lines show SD. 

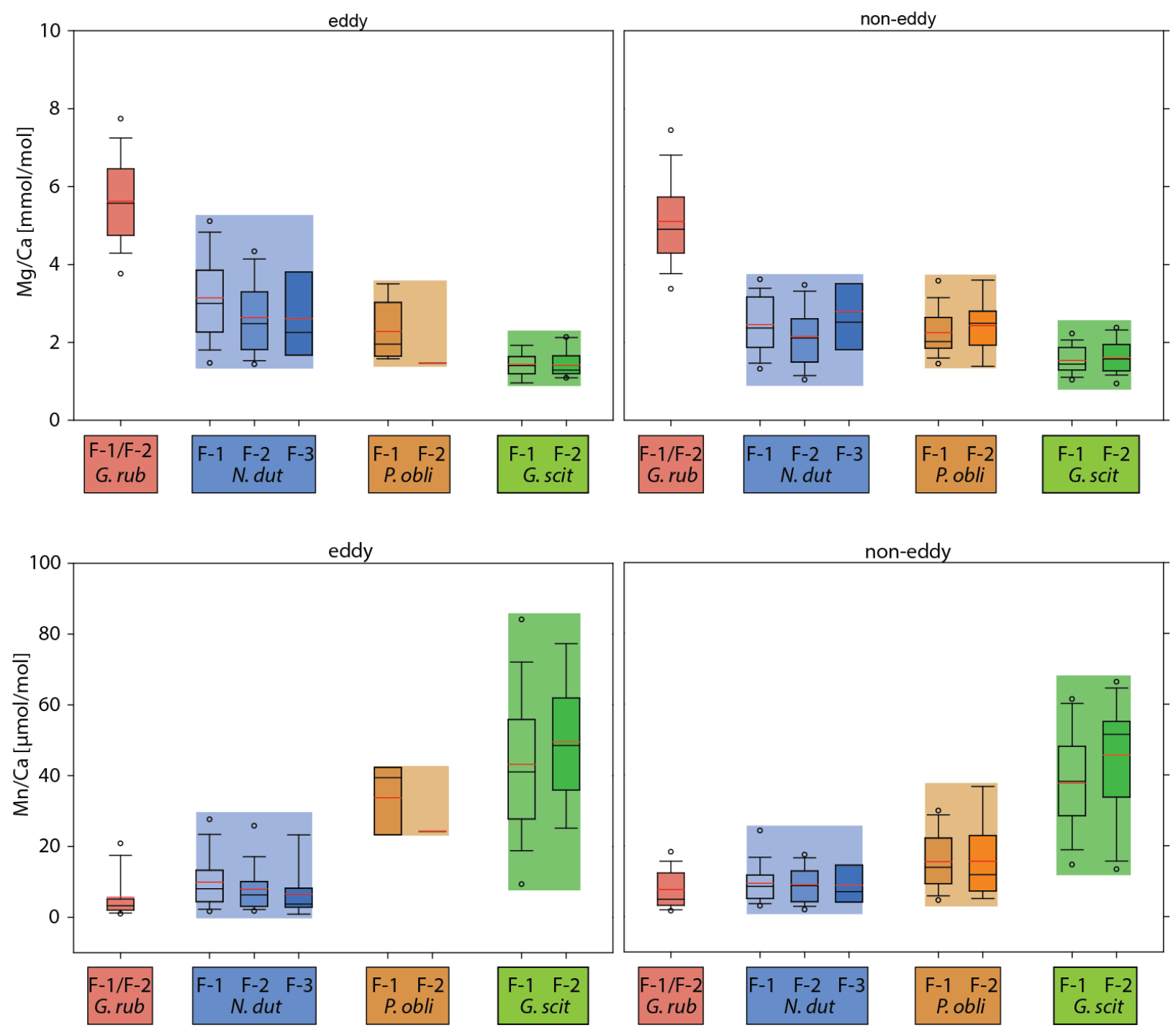

Figure 6

Figure 6: Intra-species $\mathrm{Mn} / \mathrm{Ca}$ and $\mathrm{Mg} / \mathrm{Ca}$ during eddy and non-eddy for G. ruber, $\mathrm{N}$. dutertrei, $P$. obliquiloculata and $G$. scitula, summarized in a box plot. Older chambers are indicated with darker colors. The boundary of the box closest to zero indicates the 25th percentile, a line within the box marks the median, and the boundary of the box farthest from zero indicates the 75th percentile. Whiskers (error bars) above and below the box indicate the 90th and $10^{\text {th }}$ percentiles. In addition, the graph shows mean (red line) whereas the open circles indicate the 5th and 95th percentile. The Standard percentile method uses linear interpolation to determine the percentile values. The 50th percentile (median) is indicated with the black lines within the boxes. The bounding boxes are used to graphically show overall differences between species. 

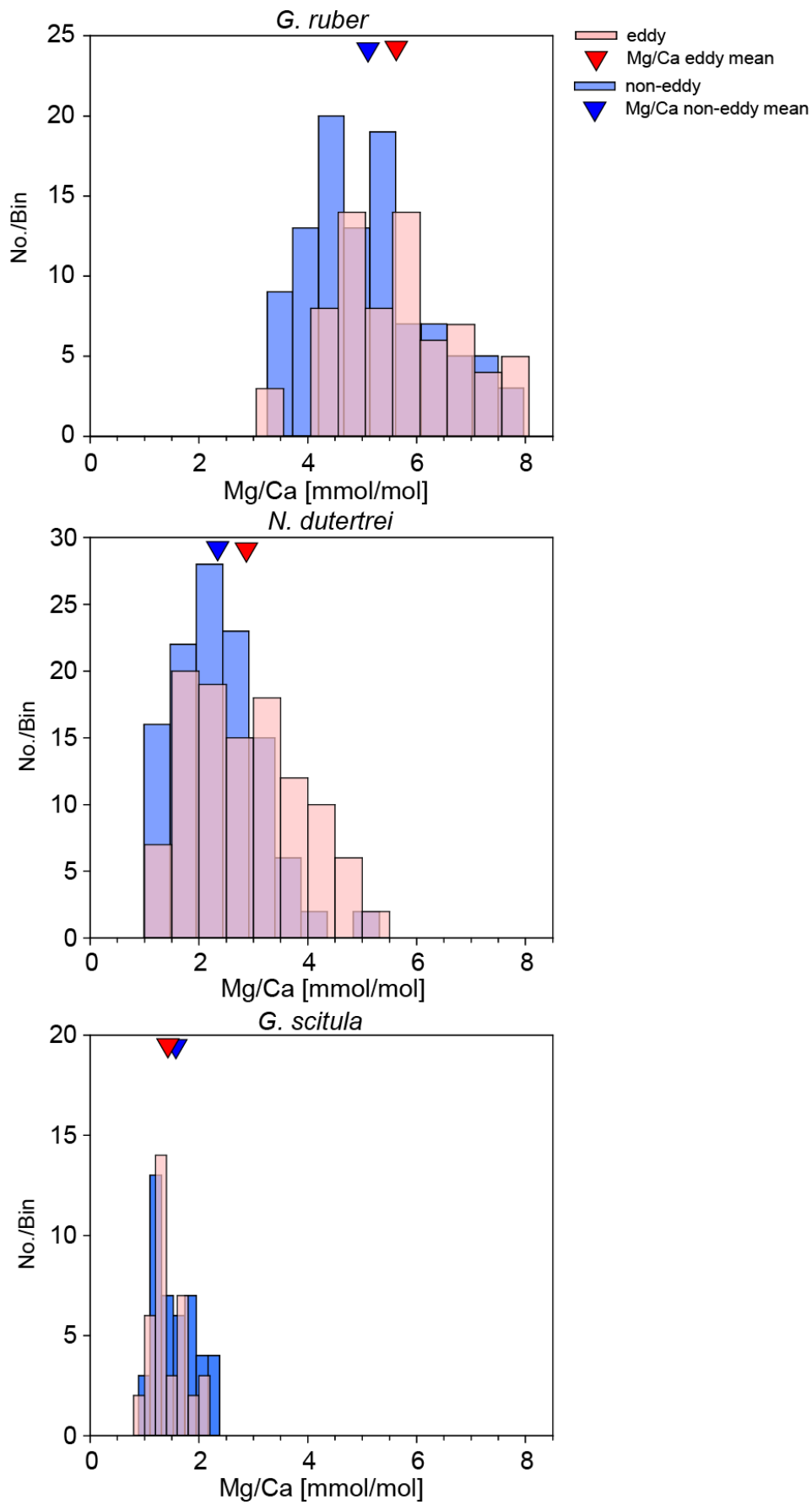

Figure 7: $\mathrm{Mg} / \mathrm{Ca}$ histograms for $\mathrm{G}$. ruber, $N$. dutertrei, and G. scitula. Histograms indicate variability, distribution and skewness of modern distribution of $\mathrm{Mg} / \mathrm{Ca}$ in the planktonic foraminifera studied here under eddy and non-eddy condition. Blue histograms represent distributions during non-eddy condition, red histograms eddy conditions. Blue down-sided triangle indicates mean $\mathrm{Mg} / \mathrm{Ca}$ value for non-eddy, red down-sided triangle indicates mean $\mathrm{Mg} / \mathrm{Ca}$ value for eddy condition. 

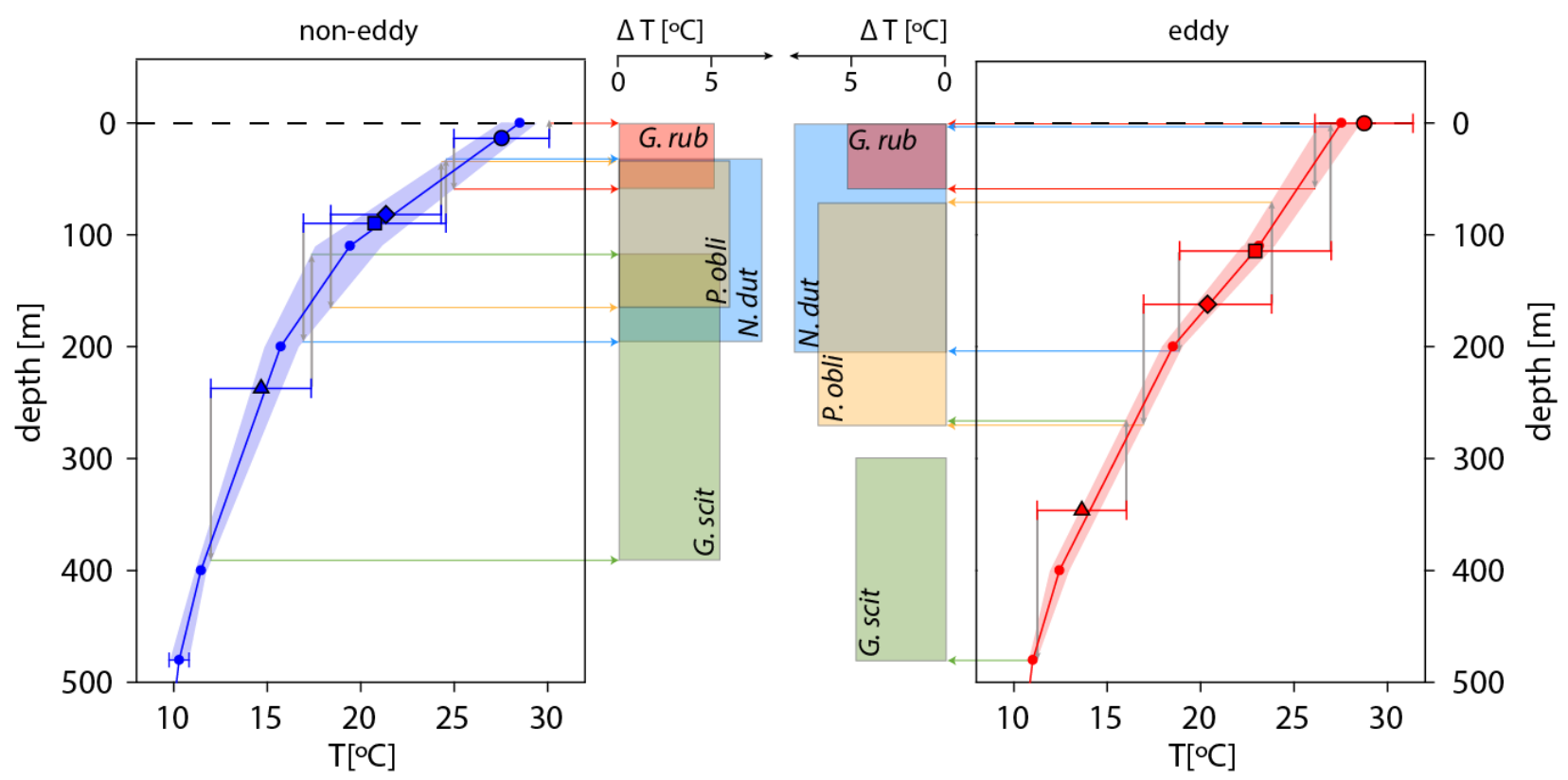

Figure 8: $\mathrm{Mg} / \mathrm{Ca}$ temperature ranges for the individual species. Depth ranges are based on cross correlating species-specific temperature ranges and temperature depth profiles. Horizontal scale in middle indicates extend of temperature range (difference between observed maximum and minimum calcification temperatures) of the individual species. 


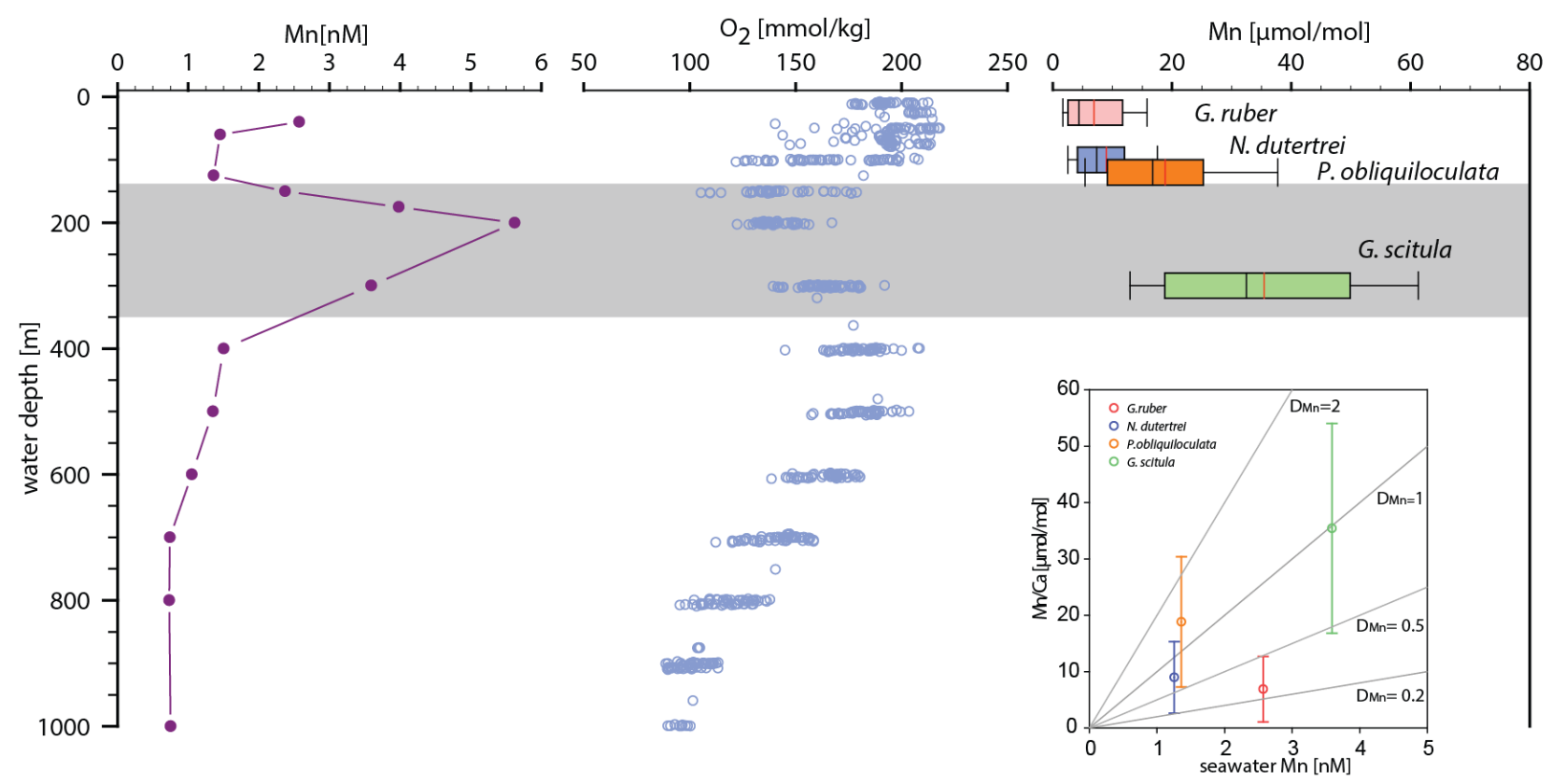

Figure 9: On the right of the panel, seawater $\mathrm{Mn}$ concentration depth profile at $14^{\circ} \mathrm{N}$ and $67^{\circ} \mathrm{E}$ (Saager et al. 1989) is indicated in purple (dot and line). In the middle of the panel, indicated by blue circles are oxygen depth profiles retrieved during the CD153b Charles Darwin Cruise (2003), D289b Discovery (2005), D301b RRS Discovery (2006) and the M75b Meteor cruises during the LOCO program. The oxygen data covers summer and winter seasons. On the right of the panel inter-species Mn/Ca differences are shown as vertical whisker plots of G. ruber (red), N. dutertrei (blue), $P$. obliquiloculata (orange) and G. scitula (green). Species specific $\mathrm{Mn} / \mathrm{Ca}$ is plotted at depth as suggested habitat depth based on literature and inferred calcification depth (Bé, 1969; Cléroux et al., 2007; Erez and Honjo, 1981; Fairbanks et al., 1982; Fallet et al., 2011; Hemleben et al., 1989; Huang et al., 2008; Itou et al., 2001; Kuroyanagi and Kawahata, 2004; Ortiz et al., 1996; Pflaumann and Jian, 1999; Ravelo and Fairbanks, 1992; Spero et al., 2003) for the species studied here. The boundary of the box closest to zero indicates the 25 th percentile, a line within the box marks the median, and the boundary of the box farthest from zero indicates the 75 th percentile. Whiskers (error bars) above and below the box indicate the 90th and $10^{\text {th }}$ percentiles. In addition, the graph shows mean (red line) whereas the open circles indicate the 5th and 95th percentile. The Standard percentile method uses linear interpolation to determine the percentile values. The 50 th percentile (median) is indicated with the black lines within the boxes. Additionally, average foraminiferal test $\mathrm{Mn} / \mathrm{Ca}$ ratios versus seawater Mn concentrations at species specific calcification depth are plotted. Extended line indicate SD of foraminiferal test $\mathrm{Mn} / \mathrm{Ca}$. Grey lines indicate a range of $\mathrm{Mn}$ partition coefficients $\left(\mathrm{D}_{\mathrm{Mn}}\right)$. Light grey horizontal bar indicates zone of oxygen minimum zone. 


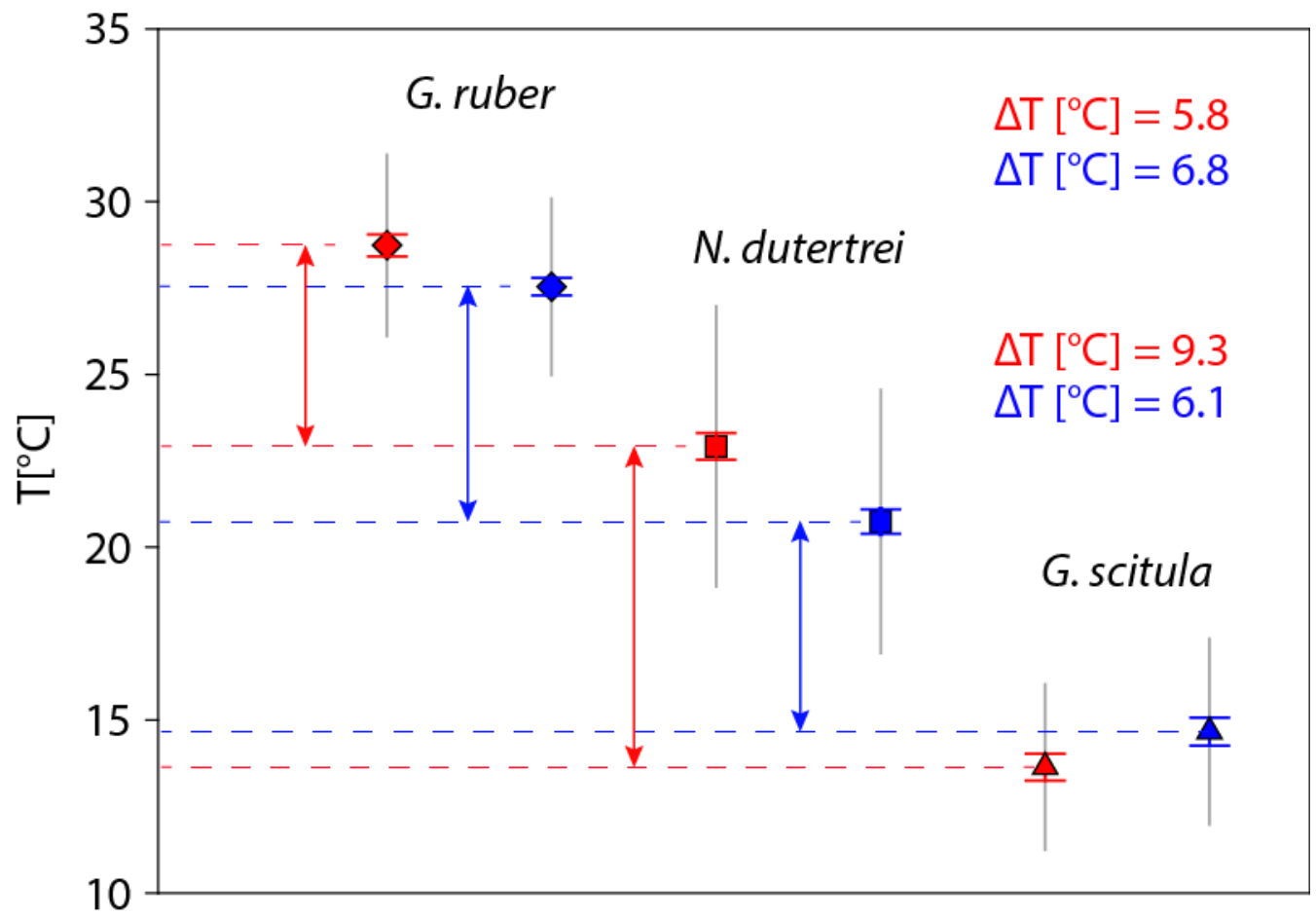

Figure 10: Inter-species comparison of calculated $\mathrm{Mg} / \mathrm{Ca}$-based temperatures during eddy and non-eddy intervals for $G$. ruber, $N$. dutertrei and $G$. scitula. Blue symbols correspond to non-eddy conditions. Error bars indicate standard error, extended lines show SD (1 sigma). 